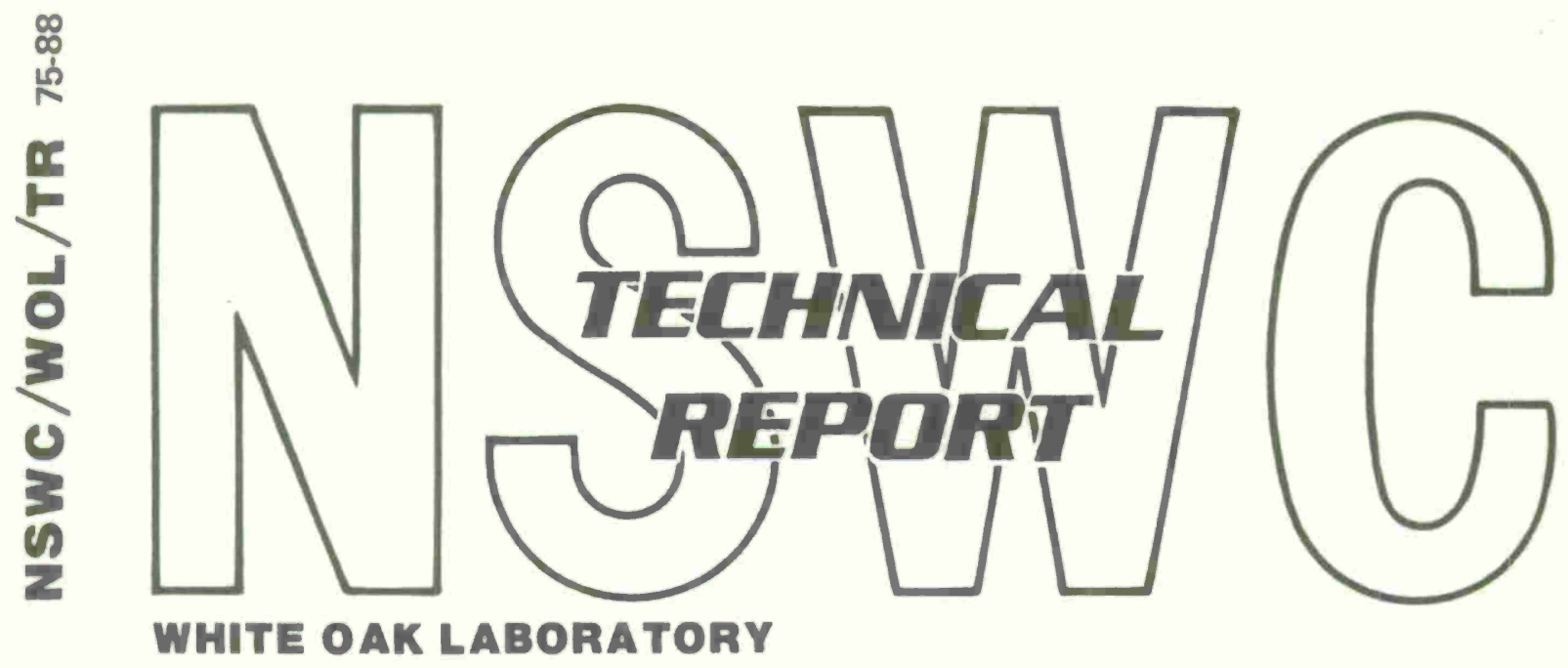

MINE WARFARE HISTORY AND TECHNOLOGY

By

Gregory K. Hartmann

NAVAL SURFACE WEAPONS CENTER

WHITE OAK LABORATORY

SILVER SPRING, MARYLAND 20910

- Approved for public release; distribution unlimited

NAVAL SURFACE WEAPONS CENTER .

WHITE OAK, SILVER SPRING, MARYLAND 20910 

SECURITY CLASSIFICATION OF THIS PAGE (Whon DAI Entored)

\begin{tabular}{|c|c|}
\hline REPORT DOCUMENTATION PAGE & $\begin{array}{l}\text { READ INSTRUCTIONS } \\
\text { BEFORE COMPLETING FORM }\end{array}$ \\
\hline $\begin{array}{l}\text { 1. REPORT NUMBER } \\
\text { NSWC/WOL/TR 75-88 }\end{array}$ & 3. RECIPIENT'S CATALOG NUMBER \\
\hline \multirow[t]{2}{*}{$\begin{array}{l}\text { 4. TITLE (and Sub(ullo) } \\
\text { MINE WARFARE } \\
\text { HISTORY AND TECHNOLOGY }\end{array}$} & 5. TYPE OF REPORT Q PERIOD COVERED \\
\hline & 6. PERFORMING ORG. REPORT NUMBER \\
\hline $\begin{array}{l}\text { 7. AUTHOR(:) } \\
\text { Gregory K. Hartmann }\end{array}$ & 8. CONTRACT OR GRANT NUMBER(0) \\
\hline $\begin{array}{l}\text { 9. PERFORMING ORGANIZATION NAME ANO ADORESS } \\
\text { Naval Surface Weapons Center } \\
\text { White Oak Laboratory } \\
\text { White Oak, Silver Spring. Maryland } 20910\end{array}$ & $\begin{array}{l}\text { 10. PROGRAM ELEMENT PROJECT, TASK } \\
\text { AREA Q WORK UNIT NUMBERS }\end{array}$ \\
\hline \multirow{2}{*}{$\begin{array}{l}\text { White Oak, Silver Spring, Maryland } 20910 \\
\text { 11. CONTROLLING OFFICE NAME AND ADDRESS }\end{array}$} & $\begin{array}{l}\text { 12. REPORT DATE } \\
1 \text { JUIY } 1975\end{array}$ \\
\hline & $\begin{array}{l}\text { 13. NUMBER OF PAGES } \\
41\end{array}$ \\
\hline \multirow[t]{2}{*}{ 14. MONITORING AGENCY NAME AODRESS(Il dillesent from Controlline Olllce) } & $\begin{array}{l}\text { 15. SECURITY CLASS. (O/ thlo roport) } \\
\text { UnClassified }\end{array}$ \\
\hline & $\begin{array}{l}\text { 15. DECLASSIFICATION/DOWNGRADING } \\
\text { SCHEDULE }\end{array}$ \\
\hline
\end{tabular}

16. DISTRIBUTION STATEMENT (OI $\mathrm{chla}$ REPORt)

Approved for public release; distribution unlimited

17. OISTRIBUTION STATEMENT (ol the ebotract onfored in Block 20, $/$ diftoront from Roport)

18. SUPPLEMENTARY NOTES

19. KEY WORDS (Contlnue on reverue olde If neceecary and Identlfy by block number)

Mine warfare

Magnetic influence mine

Minesweeping

20. ABSTRACT (Conlfnue on poverae side if neceecery and ldentffy by block number)

The history of mine warfare is traced. Technological advances applied to mine development and use have demonstrated an increasing effectiveness at modest cost. The efficacy of mines, if fully exploited, should have an important deterrent effect on conventional wars. 


\section{MINE WARFARE HISTORY AND TECHNOLOGY}

by

Gregory K. Hartmann

Formerly Technical Director

Naval Ordnance Laboratory

White Oak, Silver Spring, MD 20910

This paper has been expanded from a talk on the subject given to the Philosophical Society of Washington in April 1974.

The history of mine warfare is traced. Technological advances applied to mine development and use have demonstrated an increasing effectiveness at modest cost. The efficacy of mines, if fully exploited, should have an important deterrent effect on conventional wars.

Assistance from Mr. James Martin, Dr. William Wineland and others at NOL and later the Naval Surface Weapons Center White Oak in the preparation of this essay is acknowledged. Acknowledgement is also given to Robert Duncan, from whose book "America's Use of Sea Mines" Figures 1 through 11 were taken.

The reference cited in this paper do not appear in the text in numerical order. The reference numbers refer to the Bibliography, whose entries have been arranged in chronological order. The opinions expressed herein are those of the author and do not necessarily reflect the views of the Navy Department.

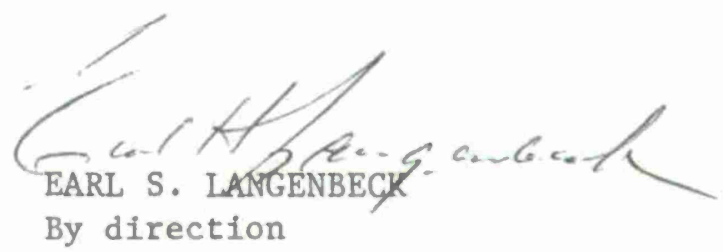





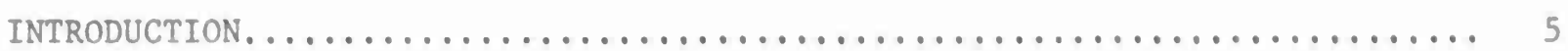

Importance of Mine Warfare............................. 5

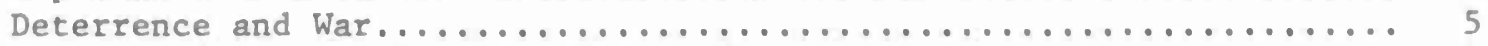

History of Mine Warfare Not Widely Known..................... 5

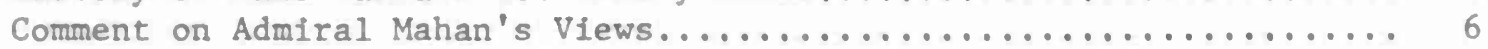

Accomplishments of U.S. and Allied Mine Warfare in World

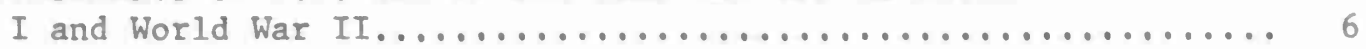

EARLY MINES ........................................... $\ldots$

What is a Mine?..................................

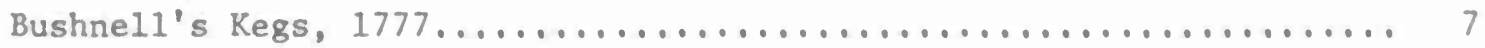

Fulton's Ideas and Experiments, 1797 to $1815 \ldots \ldots \ldots \ldots \ldots \ldots . . . . . . . .8$

Colt's New Electric Hot Wire Initiator and The Moored Control

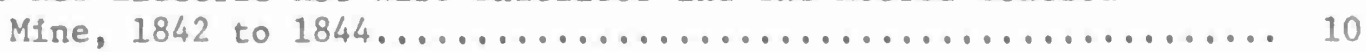

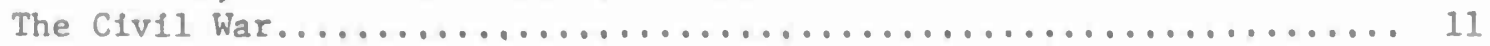

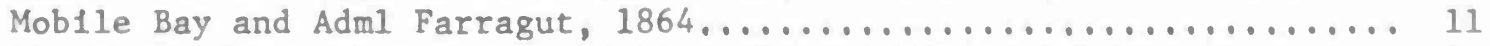

The Hague Convention and The Ethical Use of Mines, 1907........... 12

The Evolution of Explosives.............................. 12

Foreign Improvements In Mine Technology Up To World War I.......... 13

THE EARLY $20 T H-C E N T U R Y$ MINE................................ 13

The Mine Evolves Toward World War I.......................... 13

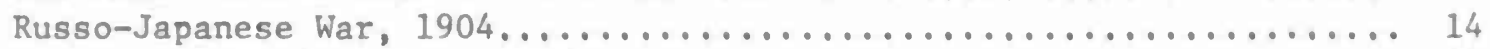

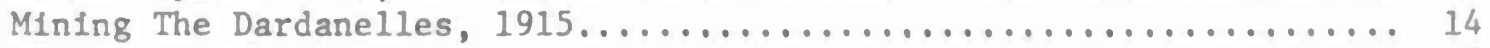

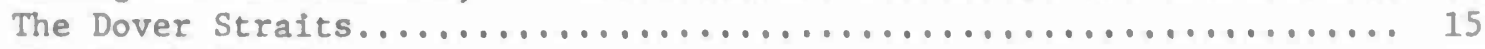

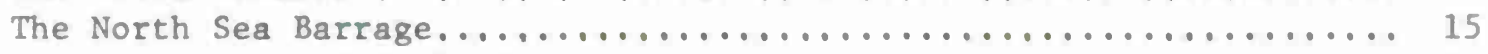

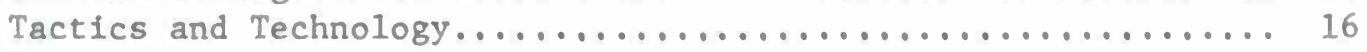

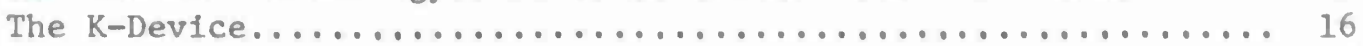

Logistics.................................... 17

Estimation of Minefields Threat...................... 17

Sweeping Problems............................... 19

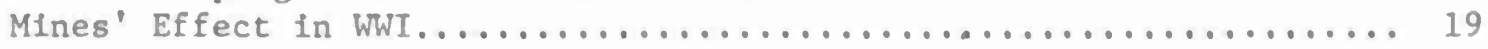

MINES COME OF AGE....................................... 20

The Blrth of the Naval Ordnance Laboratory and Its Early Struggles... 20

The Magnetic Influence Ground Mine............................ 20 
CONTENTS

MINES COME OF AGE.................................... 20

The Blrth of the Naval Ordnance Laboratory and Its Early Struggles.. 20

The Magnetic Influence Ground Mine........................ 20

Degaussing, Leads To Induction Mines..................... 21

The Total Field Mechanism................................ 22

Mine Sweeping, "Cognizance," and Policy...................... 22

United States Mine Development............................ 23

Role of U. S. Submarine-Laid Mines in the Early Pacific War........ 24

The Plan For Long-Range Aerial Mining of Japan................ 25

Results of Operation Starvation......................... 26

Summary of Mine Effectiveness in Two World Wars................. 26

Post WWII Errors - The Korean Surprise..................... 26

The Mining of Halphong Harbor Stops...................... 27

New Mine Technology.................................. 27

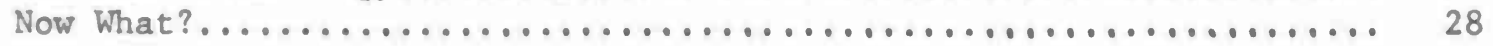

List of Illustrations

Figure

Title

Page

Bushnell's Keg 1777

Use of Drifting Mines (as sketched by Robert Fulton 1806)

Demolition of the Brig Dorothea (as sketched by Robert Fulton 1805)

Mine Mk 6 Planting Sequence

Mine Mk 6

Circuits of the K-Device

North Sea Barrage

Mine Building

Functional Diagram of Induction Type Magnetic Mines

Japanese Traffic Situation in March 1945

Japanese Traffic Situation in August 1945

Starvation Campaign April-August 1945

40

Mine Warfare in Two World Wars 
NSWC/WOL/TR 75-88

INTRODUCTION

\section{IMPORTANCE OF MINE WARFARE}

Why should mine warfare be studied when we are continuing to hope for generations of peace? Mine warfare is important because it is likely to be used in the future even if strategic deterrence successfully prevents nuclear war. Mines have been used in every major U.S. war since the American Revolution, i.e., both before and after the arrival of the nuclear age. It is, therefore, of interest to review the development and use of mines on a worldwide basis and to see how the growth of technology has influenced that use. Projections of the insights thus gained should lead to better planning for the future either to use mines advantageously or perhaps to avoid their use altogether.

\section{DETERRENCE AND WAR}

The growth of nuclear weapons in size and in number among five nations curlously, those on the U. N. Security Council - has led to the concept of deterrence. This is sald to be a realization on all sides, and particularly with the Soviet Union, that it would be mutually suicidal for anyone to resort to the strategic use of nuclear weapons. It is everyone's hope and expectation that the existence of masses of world-destroying weapons will prevent their use, at least by rational people, defining these as people who do not wish to commit suicide. It is disturbing to recall that at least one world leader did commit suicide! A further hope which is open to everyone is that if the nuclear powers can come to believe that they will never use their nuclear weapons, they might try to phase them out as unnecessary expenses. However that may be, the existence of nuclear weapons has not prevented the usual mix of large and small conflicts, since 1945 - wars, civil or international, declare or undeclared, which Lewis F. Richardson has studied in his interesting book "Statistics of Deadly Quarrels." In at least two of these wars, in which the U. S. was involved (Korea and Vietnam), the use of Naval mines played a significant role in the former in the hands of the enemy, in the latter in ours. The existence of nuclear weapons has leavened the extent to which a non-nuclear or limited war may be pushed. If one of the contestants is driven to the point where he believes he has nothing more to lose, he may then give up his nuclear restraint if he has the weapons. Nevertheless, the physics of Einstein may be the most important force for peace after all, or at least for restraint in war. Therefore, the limited war and the war with naval mines remains as a very likely possibility.

\section{HISTORY OF MINE WARFARE NOT WIDELY KNOWN}

The study of mine warfare is a relatively unknown subject outside the mine community. It has an interesting history and technology which tend to reinforce each other as time goes on and from which one can clearly see in hindsight how technology, and a very simple technology at that, has influenced tactics. All the U. S. mine development and technology for the last half century have been centered in the Naval Ordnance Laboratory at White Oak, Maryland, which has consistently devoted up to 20 percent of its effort to projects oriented toward mine warfare. There are a few publications on mine warfare in the open literature which have been consulted and in some cases heavily drawn upon in the preparation of this paper. These are listed in the bibliography in chronological order. 
It may be most appropriate to start with Mahan (reference (1)), partly to add respectability to this subject, and partly in order to make a comment about Mahan's views. It is sometimes held that Mahan was opposed to mine warfare because in order to control the sea and impose distant blockades, it was necessary to have control of the surface. If you have control of the surface, it was argued there was a positive disadvantage to placing mines in your own way, and besides that, you couldn't get minelayers into position unless you had surface control. Mines were, therefore, unnecessary as offensive weapons and were thought of only as defensive, i.e., laid in our own waters to keep out enemy ships. Offensive Naval blockade was to be done by surface warships. The new technological facts of World War II, namely, that mines could be used as offensive weapons when laid by submarine or aircraft which did not exist when Mahan wrote his books, do not dispute his views about the value of naval blockade. They merely offer a new means of achieving an objective with naval mines which was not available in Mahan's time.

\section{ACCOMPLISHMENTS OF U.S. AND ALLIED MINE WARFARE IN WORLD WAR I AND WORLD WAR II}

The accomplishments of mine warfare are noteworthy. R. C. Duncan, in his book "America's Use of Sea Mines" (reference (10)) says a total of approximately 240,000 mines were planted during World War I by all parties, and over 600 ships were sunk or critically damaged. Of these, 200 were warships, not counting an unknown list of German submarines. He further says the total ship damage from mines was greater that that by gunfire and torpedoes! It is interesting that Great Britain and Germany both had great fleets, but did not actually have battle contact sufficient to prove which was superior. The U. S. Navy, also with a great fleet of warships, probably performed its greatest war service building 100,000 and planting 56,000 mines on which no money had been spent before the declaration of war in 1917. But what about World War II? In the whole war the U. S. and U. K. laid down 300,000 mines, over $2 / 3$ of which were defensive, and sank virtually no ships. The remaining 100,000 offensive mines in all theaters sank, or damaged severely, 1700 ships. In the last four and one-half months of the mining campaign against Japan, 670 ships, including 65 warships, were sunk or severely damaged for a tonnage of 1.4 million tons. This accounted at that time for just about all the ships the Japanese had! They were thus completely cut off from supplies of oil, raw materials, and food from Asia. It has been said by Admiral Tamura (who was in charge of Japanese mine countermeasures) that had this campaign started three months earlier (or in January 1945 instead of April), Japan would probably have capitulated before the fearful event of August 6,1946, at Hiroshima (or before the atom bomb was unleashed). There is much interesting information on the mining campaign, including Japanese interviews and opinions in the Strategic Bombing Survey publication (reference (3)). That this survey is competent cannot be doubted because it was conducted by some individuals, among others, who were later to become Secretary of the Navy (Nitze), Ambassador to India (Galbraith), and Chief of Naval Operations and Chairman of the Joint Chiefs of Staff (Moorer). It is interesting that in the last four and one-half months of the

1 Mahan, Alfred Thayer, The Influence of Sea Power Upon History, 1660-1783. Boston, Little, Brown and Company, 1890.

10 Duncan, Robert Caruthers, America's Use of Sea Mines. White Oak, Md., U. S. Naval Ordnance Laboratory, 1962.

3 U.S. Strategic. Bombing Survey, The Offensive Mine Laying Campaign Against Japan. Washington, reprinted by Dept. of the Navy, Headquarters Naval Material Command, 1969. 
war the Japanese loss of shipping to mines was about equal to the U.S. 1oss of ships to German submarines in the Atlantic during the entire war. (Most of the U. S. ship loss occurred in 1942 and the first half of 1943 when about 400 ships were torpedoed. The highest U. S. monthly ship loss was 40 in May 1942 (reference (4)). (Note - the U. S. ships then averaged about 5500 tons compared with Japanese ship average of about 2000 tons at war's end.)

From such statistics we conclude that mine warfare is important. Many may be surprised at these numbers. The greater surprise should be that we are surprised; that we have not heard about this before. The public relations organization of the mine community is rather ineffective, or more accurately, rather non-existent. As we have learned, "There is nothing good or bad, but thinking makes it so." (Hamlet, Act 2) But one must at least have heard of it before thinking can begin.

EARLY MINES

\section{WHAT IS A MINE?}

Let us start at the beginning and ask what is a mine. Duncan has said it best. "The sea mine is a weapon which lies in wait for its victim. Planted under the surface of the water, possibly hidden in the mud and sand on the bottom, it may remain there for weeks or months until a vessel comes within its lethal range." From this basic definition, most of its attributes become apparent. A mine must be transported to its place of operation; it must be able to set up its operation by itself and withstand the false urges of its environment; it must have endurance; it must have sensors and intelligence to decide what to do when and if a target approaches; it must have a damage mechanism; it must be used in great numbers to improve the chance of attacking one or more targets; and, finally, it must be smart enough not to be deceived by attempts to fire it by artificial means. In other words, it must have countermeasure resistance.

BUSHNELL'S KEGS, 1777

The very first examples of a mine, namely, Bushnell's kegs, violate the definition because they did not lie in wait, but were supposed to drift slowly down the river at Philadelphia and explode against some British ships that were anchored there in the year 1777. However, I will start with this as an introduction to the technology which was first applied in this manner.

Bushnell, when a student at Yale, possibly a graduate student, had been working on underwater explosions. He later became known for his invention of a one-man submarine, The Turtle. He investigated dry gunpowder exploded under water and was sure that the underwater explosion of a charge of gunpowder against the bottom of a ship would be very serious. General Washington authorized Bushnell to attempt the destruction of the British vessels stationed in the Delaware River using his newly invented sea mine, usually referred to as a "torpedo" by Bushnell. Figure 1 is a sketch of Bushnell's Keg, the first naval mine in history.

The mine consisted of a charge of powder in a keg which was supported a few feet below the surface by a float on the surface. In the key was assembled with the powder a gun lock so adjusted that a light shock would release the hammer and fire the powder. It turned out that none of these mines contacted or damaged any British

4. Morison, Samuel Eliot, The Battle of the Atlantic, September 1939 - May 1943. Vol. 1, Boston, Little, Brown and Company, 1947. 
ships. The mines were released about Christmas Day 1777 and did not reach Philadelphia until January 5, 1778 because of the ice in the river. Because of the ice, the British ships had been brought in close to shore, so the mines bypassed them.

David Bushnell reported this exploit before the American Philosophical Society in 1799 (i.e., 22 years later) as follows:

"I fixed several kegs under water, charged with powder to explode upon touching anything as they floated along with the tide. I set them afloat in the Delaware above the English shipping at Philadelphia, December, 1777. I was unacquainted with the river, and obliged to depend upon a gentleman very imperfectly acquainted with that part of it, as I afterwards found. We went as near the shipping as he durst venture; I believe the darkness of the night greatly deceived him as it did me. We set them adrift to fall with the ebb upon the shipping. Had we been within 60 rods (990 ft.), I believe they must have fallen in with them immediately, as I designed, but as I afterwards found, they were set adrift much too far distant and did not arrive until after being detained some time by frost, they advanced in the daytime in a dispersed situation and under great disadvantages. One of them blew up a boat with several persons in it who imprudently handled it too freely and thus gave the British the alarm which brought on the 'Battle of the Kegs'."

The battle of the kegs, incidentally, was the name given to the British response to the appearance of more kegs in which they fired whole broadsides into the river to sink the kegs. It was said the firing went on from dawn to dusk and that His Excellency Lord Howe dispatched a swift sailing packet with an account of this victory to the Court of London. Others said, however, that this account was merely American propaganda.

Bushnell's mines were definitely contact drifting mines, not very safe (not safe at al1), not very effective, but using the underwater explosion long before the invention of high explosives, and a contact mechanism for initiation without human direction. They were the first mines used in the long history of warfare.

FULTON'S IDEAS AND EXPERIMENTS, 1797 to 1815

Robert Fulton is the next famous name to play a role in mine development. He divided his talents between painting and mechanical inventions. At age 21 in 1786 he sailed for England with a letter of recommendation from Benjamin Franklin to Benjamin West, a well-known painter in London. However, a few years later, he gave up painting to devote full time to what could be called marine engineering canal building, propulsion of surface vessels and then submarines. In 1797 he proposed the use of mines to Great Britain and was given some encouragement by Mr. Pitt, the Prime Minister. However, the Naval establishment was not pleased and nothing came of it except that Fulton went to France and tried to sell the idea of submarinelaid mines to Napoleon as a means of attacking Great Britain. Lord St. Vincent (Admiralty) remarked that "Pitt was the greatest fool that ever existed to encourage a mode of warfare which those that commanded the sea did not want, and which, if successful, would deprive them of it." The French gave Fulton some support and he was allowed to try out a 20-pound mine on a 40-foot sloop. The sloop was blown completely to pleces. Also he built the "Nautilus" in which he and two others descended 25 feet and stayed submerged for two hours. At about this time, 1803, the French decided against further experiments, and the British persuaded Fulton to return to England where he was paid a salary and given funds and facilities for experiments. 
He proposed that drifting mines be used to attack the French Fleet anchored at Boulogne. These mines were supplied with a clockwork mechanism which could be started when the mine was released and would explode 5 or 10 minutes later. This did not work because the French fired on the small boats which were delivering the mines and they had to be released too soon. A second military experiment was the attempt to destroy a French frigate by throwing a cable across the bow, connected to a mine at each end like a bolo. For this case, the mines exploded but the frigate was undamaged. Fulton felt this was because the mines were not properly submerged. These actions raised strong doubts about the efficacy of underwater explosions in producing damage and so in 1805 he was permitted to try yet another demonstration against a strongly built 200-ton brig, the "Dorothea." The arrangement was the same as before except that the mines were made a few pounds heavy so they would sink while the tide and the supporting lines would draw the mines in against the ship or more probably, underneath the ship.

The combined experimental-operational setup for these tests was not conducive to getting accurate data - for example - where, precisely, were the charges when they exploded? At any rate, the brig was demolished - broken in two - and although this was highly gratifying to Fulton, it greatly alarmed the British Naval authorities. They feared that such a mode of warfare might deprive them of their control of the sea. Six days after the Dorothea was blown up, Nelson destroyed the French and Spanish Fleets at Trafalgar. Therefore, England had no need of submarines, or of mines, or of Fulton. Figures 2 and 3 are interesting sketches by Fulton of the bolo mine idea, and of the demolition of the Dorothea.

Fulton returned to America and proceeded to Washington, D. C., where he represented his submarine and underwater bomb (the first moored mine) to Mr. Madison, the Secretary of State and Mr. Smith, the Secretary of the Navy. These gentlemen were much interested and granted him funds for continuing tests. In 1807 he succeeded in blowing up a brig in New York harbor but only after several attempts.

He was probably using two mines bridled together, but the mines were improperly balanced and turned over, spilling out the priming powder so that the gun lock spark had no effect. These failures made the government skeptical of the whole scheme. However, in 1810 he was again permitted to attempt to destroy a sloop but the Captain of the sloop was permitted to deploy a protective net around the ship so that the mines could not get close enough. In these experiments attempts were made also to harpoon the target ship from a small boat, as a method of getting the mine charge close to the ship. The harpoon was tied to the mine and after lodging in the ship, the tidal current was relled on to drift the mine alongside. Counterfire from the ship made this a hazardous method, and the nets defeated the mines anyway. Mr. Fulton admitted that he could not destroy a ship so protected, but pointed out that provision of such equipment for all enemy ships would be a burden and a hindrance to mobility. An impartial government committee of experts would not recommend adoption of any of Mr. Fulton's proposals. However, they overlooked the device which really had possibilities for development, namely, the moored mine. Against powder casks anchored in a harbor and floating at or near the surface of the water, equipped with firing locks which would explode the powder on contact, the Naval officers could devise no defense. Such weapons could apparently close the harbors of the United States against the vessels of an enemy. The problem of getting the explosive charge to the ship was solved by simply having the ship run into the explosive charge. You will notice that up to this point the mine had been conceived as a device for attacking an anchored ship. If the ship were moving, however, the mine could be 
anchored and would thus assume its true role of lying in wait until its victim approaches.

During the War of 1812 , Fulton made proposals to the U. S. Government to plant moored sea mines in harbors, and to use the harpoon system with mines for attack, Nothing much came of this. Fulton died in 1815, but as late as 1814 he was at the Navy Yard in Washington getting casks and other gear for experiments which I believe were never done. It is curious that Fulton's experiments were largely designed to show over and over again that an explosion would sink a ship, rather than concentrating on more reliable ways to get an explosion to occur.

The Fulton story is remarkable in that for a period of 18 years with access to the highest levels in three countries, he was unable really to get any acceptance of his ideas beyond token support for experimentation. He did quite well at this and his promotion techniques were superb. However, the technical input to the process all this time was minimal. He was stuck with the flintlock initlating mechanism, which was highly uncertain and unsafe. One suspects that even the best salesmanship will not succeed with a faulty product. But we have seen that there were other factors at work. If the product had been perfect, it would have been shunned by a sensible Navy - at least in the year 1805.

COLT'S NEW ELECTRIC HOT WIRE INITIATOR AND THE MOORED CONTROL MINE, 1842 to 1844

After Fulton's death, very little happened until the Civil War, except that Colonel Sam Colt, of revolver fame, began to experiment with mines. His main technical improvement was in the initiation system. He used an electric current from a galvanic battery flowing through a fine wire to heat the powder and cause the explosion. This technique had been used in 1839 by General Pasley of Great Britain to destroy an old wreck by an underwater explosion. Colt, however, attempted to apply the electrical initiation system systematically to controlling mine fields as defensive weapons. Most of his work was in controlled mine fields: fields of moored mines wired to shore where any mine could be fired by applying the voltage of a battery to its detonator terminals. The Secretary of War requested Congress for money for this development, which led to mine tests in New York Harbor, again blowing up an old gunboat (Boxer) in 1842. In a second test in the presence of a number of government dignitaries and congressmen, Colt blew up an old schooner in the Potomac from a shore station five miles away. This was quite a feat in those days when getting five miles of watertight cable must have been difficult. Having seen that the test was successful, Congress took no further action. Taylor Peck, in "Roundshot to Rockets" (reference (5)), says that Colt spent the summer of 1844 in the Washington Navy Yard and had been given use of all the facilities of the Yard in the preparation of an experiment with underwater explosives and mine devices. He, like Fulton, succeeded in blowing the bottom out of an old hull which promptly sank, obstructed the channel and caused the formation of an extensive sandbar which hampered movements in the Eastern Branch until 1859. No wonder some of these experiments were not too popular:

5. Peck, Taylor, Round-shot to Rockets; A History of the Washington Navy Yard and U.S. Naval Gun Factory. Annapolis, United States Naval Institute, 1949. 
The next developments in mine warfare were mothered by the necessity of the Civil War. Mines were used on a relatively large scale by the Confederates and the losses in the Federal Navy were surprisingly large. Twenty-seven Federal vessels were sunk by mines while only nine were sunk by artillery fire. The Confederate Navy, having minimal time and material, established a Torpedo Bureau and a Torpedo Corps in Richmond. The first official was none other than Matthew Fontaigne Maury, very recently of the U. S. Navy. The term "torpedo" in those days covered almost all kinds of uncontrolled or manually controlled underwater weapons. The power-driven torpedo of today was not included as it was not invented until years later. The so-called "Singer" mine is credited as being the most successful Confederate mine. It was a hand-planted, moored mine with a charge of 55 to 65 pounds of black powder. It carried a heavy cap on its upper surface which would be knocked off by ship contact. When it came off, it released a spring-driven plunger which struck a "fulminating charge," thus exploding the mine. The discovery of fulminate of mercury $\left(\mathrm{Hg}(\mathrm{ONC})_{2}\right)$ had been reported to the Royal Society in 1800 by Edward Charles Howard, FRS (brother of the 12 th Duke of Norfolk). The use of fulminate of mercury, however, was not strictly necessary. The blow of a hammer on potassium chlorate will cause an initiating flame to issue. A percussion cap is generally a mixture of the two (fulminate and potassium chlorate) in a small tube impacted at the closed end, the open end being in contact with the gunpowder charge. When used in salt water, the firing spring which was exposed to the water soon became useless because of sea growth. The Confederates also developed a chemical initiator consisting of a glass tube full of sulfuric acid. When contact broke the tube, the acid ran out over a mixture of potassium chlorate and white sugar powder which would generate sufficlent heat to ignite the gunpowder. This same idea had been previously developed by Professor Jacobi, a Russian chemist, and used in the Crimean War, 1855.

MOBILE BAY AND ADML FARRAGUT, 1864

I must mention that many moored fields were planted in the defense of Confederate cities - one of the largest, some 80 or 90 mines in the defense of Mobile, Alabama. As Duncan tells it, fortunately for Admiral Farragut, they had been planted some time before he attacked Mobile in 1864. Nevertheless, the story is incredible. Tecumseh, an ironclad vessel of 1034 tons, led the attack. Just as she reached a point where her guns could reach the defending forts, she struck a mine which exploded and sank her in a very few minutes. Brooklyn was following Tecumseh; her captain saw Tecumseh sink and saw other mines in the water. He altered the course of Brooklyn and signaled to Admiral Farragut on his flagship Hartford that torpedoes were present. Farragut was furious and signaled to Brooklyn, "Damn the torpedoes (mines), Captain Drayton, go ahead." No more mines fired. Later it was discovered that the mines were inert due to long immersion (corrosion) and wave action.

This must certainly be the first and last time that a Commander could safely ignore a minefield: But, of course, a successful Commander is one whose decisions lead to success, whatever the reasons. Admiral Farragut, incidentally, believed that the use of mines was unethical and they they were "sneak" weapons and "devilish" devices. During the Civil War, he wrote "I have never considered it (the use of mines) worthy of a chivalrous nation." 
Another account of this same opinion by Admiral Farragut is more complete and changes his meaning: Lott (reference (8)) quotes him from a statement made on March 25, 1864, to the Secretary of the Navy as follows: "Torpedoes (mines) are not so agreeable when used by both sides; therefore, I have reluctantly brought myself to it. I have always deemed it unworthy of a chivalrous nation, but it does not do to give your enemy such a decided superiority over you."

THE HAGUE CONVENTION AND THE ETHICAL USE OF MINES, 1907

Objections to mines are essentially objections to war. Perhaps the chief objection was the aspect of mine warfare in which a neutral ship or an enemy ship full of noncombatants became a victim of a mine. We notice that the drifting mine, the first example, proved to be quite ineffectual and was speedily replaced with the moored mine. The ethical questions persisted, however, and led to an International Convention Relative to the Laying of Automatic Submarine Contact Mines, adopted at The Hague in 1907. Both the United States and Great Britain objected to the use of automatic drifting mines, but finally agreed that it would be all right to use them provided they were equipped with a device to neutralize them within one hour after those who launched them lost control over them. The bad effects of mines on innocent bystanders or neutral traders, of course, are easily dealt with by declaring the mined area to be a blockade which becomes more legal as it becomes more enforceable. This Convention and the later proliferation of more devastating tactics such as mass bombing have succeeded in converting mine warfare from an underhand and nonchivalrous activity to a restrained and humanitarian form of persuasion.

\section{THE EVOLUTION OF EXPLOSIVES}

In the period between the Civil War and World War I, very little happened to advance the art. In 1898, a Bureau of Ordnance Annual Report refers to mine design work at the Naval Torpedo Station (Newport, R. I.) and states that "gun cotton mines were prepared and issued." This was a technological advance - to replace the old gunpowder charge with a more powerful explosive called gun cotton, consisting of nitrated cellulose first prepared in 1838 by Pelouze, and improved by processing in 1865 by Sir Frederick Abel. It was thus that gunpowder lost its 600-year monopoly as the world's only military explosive. (In 1242 Roger Bacon "published" in a secret code the composition of gunpowder that would explode.) There is another line of high-energy materials which did not find its way into mines although some of its descendants were extensively used for gun propellants. This group of materials comes from the nitration of glycerin, first accomplished in 1846 by an Italian chemist named Sobero. Twenty years later, Nobel invented dynamite by absorbing nitroglycerin in diatomaceous earth, also called kieselguhr, which absorbs three or four times its weight of nitroglycerin. The interesting result of this was that the explosive was now safe to transport and yet could be detonated. It was of great commercial value but not used in munitions because of its bullet sensitivity. It remained for Nobel in 1888 to make another remarkable synthesis, namely the combination of nitrated cotton and nitrated glycerin to make a slow burning, i.e., nondetonating, propellant called Ballistite or smokeless powder. This, of course, was used in guns but not in munitions because it would not generate the sudden pressure needed to make fragments or create strong underwater shock.

8. Lott, Arnold S., Most Dangerous Sea; A History of Mine Warfare and an Account of U.S. Navy Mine Warfare Operations in World War II and Korea. Annapolis, U.S. Naval Institute, 1959. 
Although the U. S. had been doing very little on the mine front between the Civil War and World War I, other nations had been busy improving their mine capabilities.

In 1868 a scheme was evolved right after the German Austrian War of 1866 for firing contact mines, called the Hertz horn. This consisted of an electrolyte (potassium bichromate solution) in a glass tube sheathed in a soft metal horn, usually lead, which stuck outside the mine. When bent by contact with a ship, the glass would break and the electrolyte would complete the circuit in a battery which would then fire the electric detonator. This became standard for contact mines. (Heinrich Hertz of electromagnetic fame 1857-1894) could hardly be the author of this, for he was eleven years old at the time.)

The automatic anchor, developed in the late nineteenth century at HMS Vernon at Portsmouth, made it possible to moor mines quickly at predetermined depth without measuring the water depth, provided it did not exceed the maximum cable length available. Figure 4 shows how this scheme worked. A plummet weight descends faster than the anchor until it is a distance below equal to the depth desired eventually for the mine case. At this point plummet and anchor sink together leaving the case on the surface. When the plummet hits the bottom, the loss of tension locks the cable and the anchor pulls the mine down below the surface an amount equal to the distance the plummet lay below the anchor. It is not necessary to know the depth of the water!

Another improvement made by HMS Vernon consisted of a new firing device, namely, an inertial switch which would connect to the detonator the voltage from a battery placed in the mine itself. This is the first instance of a mine carrying its own battery.

THE EARLY 20TH-CENTURY MINE

THE MINE EVOLVES TOWARD WORLD WAR I

The matter of armaments seemed to be fairly international before World War I. In 1909, the Bureau of Ordnance issued a pamphlet describing its Mk 2 Naval Defense Mine which was designed and manufactured for it by a French firm, Sauter-Harlé of Paris. This mine also had something new - an automatic anchor which fixed the depth of the case at a predetermined level. About 1915, the Bureau began to manufacture its own mines using a design owned by Vickers Company of England. This mine also had an automatic anchor and was loaded with TNT instead of gun cotton. [The first nitrated benzene ring explosive, picric acid (nitrated phenol), was not known as an explosive until 1871. It was introduced as a filling for shells in 1885 and from that time the coal tar industry rapidly developed other explosives, including TNT, which became plentiful in World War I.] In 1917 when we entered World War I, we discovered that the mines we were manufacturing following a British design, which they had had at the beginning of the war, had been found to be quite unsatisfactory by the British. And so in 1917 we were in much the same position with respect to mine warfare that we were in at the conclusion of the Civil War. 
RUSSO-JAPANESE WAR, 1904

Operationally, various powers had been using mines - all moored - as follows during this period.

Russians used mines in the Crimean War, 1857, in a Turkish War, 1877, and in the Japanese War, 1904. In this last war, three battleships, five cruisers, four destroyers, two torpedo boats, one minelayer, and one gunboat were sunk on both sides, while other ships were severely damaged by mines. The Russians laid the first mines in that war. There are two stories worth mentioning about it. One is that the Russian minelayer "Yenisei" of 2500 tons put down a field of 300 moored mines in the approaches to Port Arthur on February 7, 1904, blundered into her own minefield and was blown up by a mine she had just laid. This event stressed the importance of good navigation or, failing that, of a delayed arming mechanism so that minelayers could get clear. The other story relates to the Russian loss of their 11,000-ton battleship "Petropavlovsk" which hit two mines and went down while crossing a known Japanese minefield. The Russian Admiral Makaroff lost his life in that event. He refused to consider mines dangerous and would not change course! Perhaps he was following Admiral Farragut's example without his luck.

The Russo-Japanese War showed that mines were formidable weapons. The effectiveness and economy of mine warfare was especially noted by the Germans. By 1914, just ten years later, they had accumulated a good supply of mines and were ready to use them. The British were equally ready. They had a dozen old gunboats converted to mine sweepers and several cruisers fitted as minelayers, and a supply of 4000 mines.

\section{MINING THE DARDANELLES, 1915}

As an introduction to the use of mines in World War I, it is illuminating to note the extraordinary events surrounding the entry of Turkey into the war and the mining of the Dardanelles. As Barbara Tuchman describes in a fascinating account (reference (11)), the Germans were most anxious to obtain an active alliance with the Turks in order to sever the connection between Russian ports in the Black Sea and the Allied fleets in the Mediterranean. At the outbreak of war, there were two German warships, the battle cruiser GOEBEN and the light cruiser BRESLAU in the Mediterranean. These ships evaded the British and French forces in the Mediterranean and arrived in a few days at Constantinople after demanding and receiving from the Turks a safe conduct through the Dardanelles. In the Tuchman account, there is no mention of mines in the Dardanelles in August, although Meacham (reference (13)) cites Turkish records which show the first mines laid on 3 August. The same sources show, however, that 150 of the mines in the Kephoz barrier were laid after 1 January 1915 and that the other 200 were laid between August, and January, i.e., after the German warships had passed through. In late October, these same ships flying Turkish flags but still under the command of German Admiral Souchon steamed into the Black Sea and shelled Odessa and other ports, sinking a Russian gunboat. This calculated action caused Russia to declare war on Turkey and thus finally brought Turkey actively into the war on the side of the central powers. Britain and France declared war on Turkey on November 5 and immediately began plans to force the Dardanelles, capture Constantinople and again open the Black Sea to Russia. Tuchman

11. Tuchman, Barbara, The Guns of August. New York, MacMillan and Company, 1962.

13. Meacham, Cdr. James A., "Four Mining Campaigns: An Historical Analysis of the Decisions of the Commanders", Naval War College Review, Vol. XIX, No. 10, June 1967 
says, "With the Black Sea closed, her (Turkey's) exports dropped by 98 percent and her imports by 95 percent. The cutting off of Russia with all its consequences, the vain and sanguinary tragedy of Gallipoli, the diversion of Allied strength in the campaigns of Mesopotamia, Suez and Palestine, the ultimate breakup of the Ottoman Empire, the subsequent history of the Middle East, followed from the voyage of the Goeben." We should note that these things would not have followed if the British and French fleets had been able to force the Dardanelles on 18 March 1915, the date of their maximum effort. They were unable to do so because of a very small number of mines which on that day sank the French battleship BOUVET with a loss of 638 men out of a complement of 709; sank two British cruisers, HMS IRRESISTIBLE and HSM OCEAN; and damaged the HMS INFLEXIBLE so that it had to be beached*. Meacham quotes the conclusion reached by the admirals at the close of day: "The battleships could not force the straits until the mine field had been cleared - the mine field could not be cleared until the concealed guns which defended them could be destroyed, and they could not be destroyed until the Peninsula Gallipoli was in our hands; hence we should have to seize it with the Army."

Thus began one of the most miserable land campaigns in history resulting in failure. Meacham says "The enterprise was finally given up - but the mines were still in place at the end of the war and sweepers had to precede the triumphal entry of British warships past the silent guns into Constantinople on 12 November 1918."

\section{THE DOVER STRAITS}

We now move from the Dardanelles in 1915 to the English Channel in 1917. Many German submarines based in several ports in Flanders at that time passed south through the Channel on their route to their Atlantic hunting grounds. In the Dover area, they were opposed by various means including mine fields, nets, and surface patrols - none of which was very effective. The unrestricted submarine warfare against British shipping had become critical for Great Britain and gave new emphasis to plans for closing the Dover Straits to submarines. Admiral Keyes, a veteran of the defeat at Kephoz, had a great belief in the value of mining not shared by the Senior Naval Officer at Dover, a Vice Admiral Bacon. The argument was settled eventually by the assignment of Keyes to relieve Bacon. The Keyes plan consisted of a deep moored mine field of over 5000 mines from Folkestone to Cap Gris Nez plus a large surface patrol using seach lights and flares at night. We are told by Meacham that up to this time, the British mines were both ineffective and unreliable. "However, a new mine (designated H2) using chemical horns copied from captured German weapons became available for the project commencing in November 1917. Planting started in Decembei and was completed before the new year. This field, with a calculated threat of between .35 and .45 , forced the Germans after several losses to give up the Dover route and to seek access to the Atlantic through the longer northern route.

\section{THE NORTH SEA BARRAGE}

We are now on the threshold of a very wide-scale use of mines, although even here it was a last-minute effort on the part of the U. S. and obviously would have

*These ships were sunk by a line of 20 mines which were secretly laid during the night of 7-8 March several miles south of the known Kephoz mine field. 
been far more effective if it had been done at the beginning, in 1914, instead of at the end, in 1918! As has been said, the U. S. was manufacturing an obsolete British moored mine during the first years of the war, while the British were busy convincing themselves that their mine was really not a suitable device - especlally for so ambitious a project as blocking off the North Sea exit to the Atlantic for German submarines. However, in 1917 when the U. S. got into the war, a great enthusiasm developed in this country for combating the terrible submarine menace. Inventors all over the country proposed various schemes, and one of these made use of the fact that a steel ship coming in contact with a copper wire in salt water could produce a galvanic current which could be made to fire a mine. The virtue of the copper wire or antenna was that it could be deployed by its own float (submerged) so that the ship or submarine would not have to hit the mine - it could merely run into the wire but would still be within lethal range of the explosion. This extended the cross-sectional area within which passage was unsafe by a factor of at least three, so that the number of mines necessary to seal off the North Sea became much more manageable. A great deal of enthusiasm developed in the Bureau of Ordnance for this project, which was an enormous undertaking starting from scratch with minimal time, although no one then knew that the war would be over in eighteen months. The conviction that the project could be undertaken successfully stemmed from the state of the technology at the time. The electrolytic firing device was a bit risky because it had not been tried out on what we today would call an evaluation lot. However, the newly designed mines could be laid automatically just by steaming along and dropping them over the fantail from built-in rails. The automatic anchor took care of the depth setting. The charge consisted of 300 pounds of TNT. Calculations showed that approximately 100,000 mines in the North Sea would substantially inhibit submarine passage. The Admiralty gave its approval somewhat reluctantly for the mine barrage in October 1917, and the Secretary of the Navy authorized the Bureau of Ordnance to proceed with the procurement of 100,000 mines, designated Mk 6 , at a cost of 40 million dollars, or $\$ 400$ per mine. In today's dollars, I suppose this would be of the order of $\$ 4000$ each. Figure 5 is a photograph of the famous Mk 6 complete with anchor, plummet and antenna float.

TACTICS AND TECHNOLOGY. In looking at these historical matters, it is clear that the existence of a technology allows its application to be made to a particular tactic. The desire for a given capability, on the other hand, does not lead directly to the development of the technology which would be used to provide it. The objective of a tactic is obvious, but where a piece of technology may be applied is not clear in advance. An unexpected or peripheral piece of technology may become the solution in an unforeseen manner. Of course, the interplay of tactics and technology is a feedback process in which progress may be made more rapidly by reducing the feedback time. Ways to increase this time include reduction of research and development funding, reduction in technical meetings, reduction in travel and telephones, reduction in recruiting, and other modest economies. Progress can be greatly reduced by these means without actually saving very much money. However, during the crisis of war, such economies are fortunately not practiced.

THE K-DEVICE. The electrolytic firing influence called the K-device (why, I don't know) worked as depicted in Figure 6 . The $\mathrm{K}$-device was part of a proposal made by Mr. Ralph C. Browne of Salem, Massachusetts, who worked for the L. E. Knott Apparatus Company of Cambridge, Massachusetts. His proposal was for a sub- 
merged gun. CDR. Fullinwider of BuOrd saw the possibility of the electrolytic scheme for a mine firing device and persuaded Browne to work on this application. It called for a sensitive relay, a self-contained battery, which became a limitation on the life of the mine, an electric detonator, and a hydrostatic safety switch. There was also a hydrostat to release the antenna float when the case reached its planned depth.

The copper wire was carefully insulated from the steel float and the steel case. Because the wire was connected only to insulated copper plates, there was no flow of current when the mine was immersed in salt water, as all of the copper was at the same potential. However, when the steel hull of a ship made contact with the copper antenna wire, the steel became one electrode of an electrolytic cell connected by the wire to the copper plates which became the other electrode. A current then flowed through the antenna wire with the return path being the sea water itself. This small current closed the sensitive relay which connected the firing battery to the electric detonator.

LOGISTICS. In order to meet all the requirements, it was necessary to manufacture, load and ship these mines and lay them at the rate of 1000 per day: To meet the explosive loading requirement, a new plant was built at St. Julian's Creek, Virginia. Ground was broken in October 1917 and it was ready for operation in March 1918. This plant loaded over 73,000 mines at the rate of 300,000 pounds of TNT per day in 1000 mine cases without an accident! Twenty freighters were assigned as transports for the various mine parts being manufactured all over the country. The mines were assembled at two depots in Scotland at the rate of up to 6000 per week and were first available when the first minelayers arrived in June 1918. Since the Navy initially had only two minelayers, eight additional commercial vessels had to be modified to serve as minelayers. The location and extent of the Barrage is shown in Figure 7. Laying was done in a total of 14 excursions up through October 30, 1918. The U. S. planted 56,611 mines of American manufacture and the British planted 16,300 mines of British manufacture. The war ended before the whole plan was carried out.

The distance from Scotland to Norway is about 250 nautical miles. The water depth varies from about 300 feet over most of the distance to about 600 feet at the eastern end. The middle section (marked A, 134 miles long) was mined from 10 feet down to 300 feet, 50 miles wide with U. S. mines. There were no plans for surface traffic here. The section near the Orkneys was mined with British mines from 65 feet to 100 feet deep - the section being 50 miles long and 20 miles wide. Finally, the Norway sector was mined by British mines again from 65 feet to 200 feet deep, the sector being 60 miles long and 50 miles wide. Surface traffic was thus possible without risk, assuming that the mines stayed moored. The mines were also kept out of the Orkneys proper so that passage between islands for British units was safe.

ESTIMATION OF MINEFIELDS THREAT. Let us try to estimate the threat of the American section of the Barrage which was 134 nautical miles across and which contained 56,611 mines planted in three sections on the east side and four sections on the west side. The sections were 2000 yards wide. The mines were planted from ships steaming in parallel putting the mines in 150 feet apart. Later it seems in the laying process they were placed 250 to 300 feet apart because of countermining which had occurred earlier. This is described in reference (2). Assume an average

2 U.S. Office of Naval Records and Library, "The Northern Barrage and Other Mining Activities". Pub. under the direction of the Hon. Josephus Daniels, Secretary of the Navy. Washington, Gov't. Printing office, 1920. 
separation of 200 feet for illustrative purposes. Then there would be 30 mines per mile in a row and in order to get all the mines in place there would have to be 14 rows of mines, each row being 134 miles long. If the water is 300 feet deep, the total cross section area assigned to one mine is 200 feet times 300 feet, whereas the actual area forbidden to a submarine is twice the radius of the submarine times the antenna wire length. Hence, the probability of the submarine (diameter 25 feet) running into the mine is

$$
\frac{25 \times 100}{200 \times 300} \text { or } \frac{1}{24} \text {. }
$$

Probability of safe passage through 14 rows is

$$
\left(\frac{23}{24}\right)^{14}
$$

or 0.55 . Hence, the mine fleld threat is .45 going through one way. The chance of going out and back safely is only .3. These are not very good odds, to say the least, for the enemy submarine. [Note: If mines are taken to be 300 feet apart, there will be 21 rows and the threat rises somewhat to .58.]

It is interesting to note that under the pressure of wartime enthusiasm and haste, the Navy embarked on this gigantic project - its largest project in the war with total commitment to the manufacture and use of a mine which had not undergone any appreciable performance tests beforehand. This absolute "no-no" was forced on the Navy by the lack of time which is another way to say lack of preparedness. As it was, there is no way to determine how effective the planted mine field was. On planting, some 4 to 8 percent of the mines would fire soon after laying. If any of the automatic features failed to work, then a floating mine, a sunken mine, a dead mine or a premature could occur. All of these things were observed. Nevertheless, the field sank six submarines in those last months of the war, and at least that many were damaged and returned to port. Submarines that made it to the Atlantic were delayed by picking their way through the weak areas of the field and, thus, had much reduced time on station. Admiral Strauss*, in summing up the effort, remarked that "the mine as a weapon of nautical warfare now presents greater possibilities than ever before. the U. S. in less than one year was able to construct a squadron of minelayers and produce enough mines to keep them constantly employed laying in each excursion of four hours more mines than the U. S. had ever possessed prior to the war. ..... This mine proved, perhaps, the most efficient single weapon against enemy submarines."

An attempt to evaluate the mine effectiveness occurs in "Navy Ordnance Activities, World War I 1917-1918" in which costs are listed as follows:

56,611 mines at $\$ 17.5$ million rounded off

68,300 mines at $\$ 21.1$ million rounded of $f$

\footnotetext{
*Rear Admiral Joseph Strauss, U.S.N.

Commander, Mine Force, U.S. Atlantic Fleet

U.S. Naval Forces Operating in European Waters
} 

Mine layers - procurement, repair, alternations, operating cost

Mine carriers

Mine bases Invergordon Inverness
$\$ 20.3$ million

$$
7.9
$$

$\overline{\$ 79.4}$ million

The value of shipping lost to enemy submarine action prior to the barrage was estimated at greater than $\$ 70 \mathrm{M}$ per month. The drop in losses after the barrage was in place is not stated.

SWEEPING PROBLEMS. It is ironic and possibly accounts for some of the adverse feelings about mines in some quarters of the Navy, that no sooner had the giant effort of planting some 72,000 mines been ended, than it was necessary to sweep them up. The evidence shows that the peacetime minesweeping effort was more hazardous than the wartime mine planting effort. Sweeping was accomplished by towing a submerged loop of wire between two ships - one of which had to pass over the mine field [Perhaps this gave rise to the saying that sweeping is such a drag]. The K-device could be nullified by passing a strong current from ship to sea through a towed cable insulated except at the end. This artificially raised the potential of the ship to that of the copper on the mine and nullified the mine firing current. However, the chief danger remained in tangling the mine cables with the sweep cable with the result that to get them untangled a mine might be brought near to the sweeping ship. Another hazard was brought on by countermining a mine which happened to be near the sweeper when a sweep wire properly fired a more distant mine. In the course of the minesweeping operations which continued until September 1919, there were several mine explosions, one of which killed the sweeper's captain and injured several crew members. Nearly 100 ships, trawlers, and sub chasers had been used in this operation. Upon completion, Admiral Strauss received the following message from SECNAV: "This most arduous and dangerous work, one of the greatest and most hazardous tasks undertaken by the Navy, and which has been carried on with cheerfulness and integrity, will go down in the annals of history as one of the Navy's greatest achievements."

\section{MINES' EFFECT IN WWI}

To conclude the comments on World War I, it is true though not generally highlighted that as far as the U.S. Navy was concerned, there were no major battles with enemy ships in which guns and armor were used. Nor, in fact, was there ever a real showdown between the British and German surface Navies except for the controversial action at Jutland. Mines, however, created havoc out of all proportion when used by either side. Even the British Secretary of War, Lord Kitchener, was killed in 1914 when the cruiser HAMPSHIRE was mined and sank when he was aboard. 
In 1919, the Bureau of Ordnance was able to dedicate a small new building in the Washington Navy Yard to the design and development of naval mines. This was a two-story building 120 feet long and 60 feet wide, officially called "The Mine Building," which 10 years later, after certain vicissitudes, was renamed the Naval Ordnance Laboratory and given a measure of control over its own projects. Figure 8 , showing the building, also features a tank in rear for moored mine tests. The tasks of the Laboratory were to improve the Mk 6 Mine; to improve the K-type firing device; to investigate magnetic and acoustic ship influences; to design a magnetic firing device; and to design a 21-inch cylindrical mine (also moored) to be laid by discharging it from a standard submarine torpedo tube and fired by Hertz horn. These assignments far exceeded the abilities of The Mine Building to perform, because of limitations in staff and money.

In 1929, the Senior Inspector of the Gun Factory recommended to the Chief of the Bureau of Ordnance that a board be appointed to study the work of the Mine Building and recommend how this work could be carried on by other sections of the Gun Factory. The final report was entirely contrary to the Inspector's ideas. It recommended that the newly named Laboratory be authorized to work on any ordnance development or research problem assigned to it and that its staff be increased as required. The Chief approved the recommendations of the board except that there was to be no increase in the staff! What progress might have occurred was very much inhibited by economy. As Duncan (reference (10)) says, "Promotion of personnel was almost unheard of, new employees were out of the question, machine tools were largely those discarded by other shops in the Yard, and purchases of experimental equipment were nil."'

".....At one time work on depth charges was limited to $\$ 25$ per month or one machinist for two days. All purchases above $\$ 10$ had to be submitted as formal requisitions on which bids would be requested, and then the article was purchased from the lowest bidder. One urgent job required a small d.c. motor that could be bought from any motor manufacturer for about $\$ 15$. In order to save time, the Laboratory obtained one day a purchase order of less than $\$ 10$ for the motor frame, and the next. day an order, also for less than $\$ 10$, for the motor armature. The supplier was told that the Laboratory would accept the two parts assembled." It must be remembered that all of this went on in the doldrums of the great depression. However, attitude and understanding could have gone a long way toward mitigating the effects of such petty economy. It appears that for a few years after World War I the Bureau of Ordnance had a Research fund for mine work. This fund, at the Bureau's own request, was added to the general appropriation and speedily became lost for mine work thereafter.

\section{THE MAGNETIC INFLUENCE GROUND MINE}

And so this brings us to 1939 with the U. S. more or less where it had been 20 years before, but with a terrible new mine threat in the hands of the Germans

10 Duncan, Robert Caruthers, America's Use of Sea Mines. White Oak, Md., U.S. Naval Ordnance Laboratory, 1962. 
and with some degree of preparation avallable on the part of the British. Up until the war started, the U. S. got very little information concerning mine R\&D activity in Great Britain or Germany. The British had, however, improved their moored mine, had studied magnetic needle type and magnetic inductive mines and had considered methods to reduce a ship's magnetic field. Germany had developed a magnetic needle type mine deliverable by aircraft (and submarines) and had also been ignorant of British countermeasure work. They assumed that the British would be helpless against their magnetic mines for at least a year or two. of such miscalculations are victories and defeats made.

The new idea unleashed on the world at that time was that the magnetic field change due to a passing ship could be detected by a stationary mine lying on the bottom. Up to that time all offensive mines had been moored. Since the mine did not float, it could consist entirely of mechanism and explosive. There was no longer any need to transport a great inert anchor mechanism. The greater explosive charge made the mine effective in fairly deep water - say, up to 200 feet, although most harbors and their approaches were much shallower - say, 40 feet for dredged channels. But the chief advance was the possibility of laying these mines from aircraft, replenishing them by aircraft with no danger to the German mine layers from their own mines. It was, of course, necessary to retard the fall of the mines by automatic parachutes so they would survive the impact on water. Very early in the war, in November 1939, the British were fortunate enough to find a mine which had been laid on land in error (on the flats at Shoeburyness in the Thames estuary), to disarm it without blowing themselves up, and hence to establish what the vaunted secret weapon was. A recovered mine was sent to NOL in 1940 and this led to a decision to make a copy of this device. The firing device consisted of a magnetic needle mounted in gimbals and released on a knife edge after planting and after springs had been automatically adjusted by clockwork so that the needle was in equilibrium with the vertical ambient magnetic field. In this way, the adjustment to the local field, which was, of course, a function of latitude and other variables, was handled.

The mechanism was expensive, delicate, and required careful machining. The mine required a non magnetic case which was made of aluminum. Compared with the later induction mine, it was a clumsy device - but it did work to the point of practicality and was a great improvement over the American gadget which involved two magnetic needles and which behaved so capriciously that it had never been seriously pursued. There was a limit to the sensitivity of this needle mechanism, because of friction, the necessity for damping, and the limited magnetic moment of the needle.

\section{DEGAUSSING LEADS TO INDUCTION MINES}

A way to deal with the magnetic mine was to remove the magnetic field from the ship, a procedure called degaussing. The Laboratory became involved in this, and designed the coils to be installed on ships and ship ranges. The Laboratory designed the magnetometers to measure the net fields of ships both before and after degaussing. During the war nearly 13,000 ships were fitted with degaussing equipment in the United States at a cost of approximately $\$ 300$ million.

Now in measuring the field of a ship, it was found more practical to let the ship pass over a small coil in which wire was wrapped around a permalloy core, than to use the large loops the British started with. Such a coil could be mounted in a copper pipe and driven into the bottom of the range where it would be held still and leakage problems were minimized. These induction coils became the sensitive elements for the next improvement in mine design. The great advantage of this is 
that no mechanical adjustment is required for the ambient earth's field; a steel case can be used; any change of any component of the field can be detected, and the signal can be required to correspond to a ship's signature, that is, signal processing can begin to enter the mine developer's bag of tricks. Figure 9 illustrates the principle of operation of the magnetic induction firing device.

\section{THE TOTAL FIELD MECHANISM}

It is significant that the induction mine could not be moored because it would fire itself moving about in the earth's field, whereas up to this point all mines had been moored. This led to an effort to find a way to use a magnetic firing influence in a mine which itself was free to move and in a depth charge which was sinking and perhaps tumbling freely. The answer was to use three pickup coils mutually at right angles and to add their squared outputs so that the result was a measure of the total magnetic field. This was then independent of the orientation of the body in it. It was very convenient to have a magnetic material for the core in which the magnetic induction was proportional to the square of the magnetic field with minimal hysteresis. This led to the development of the material called Parabonol but that is another story.

MINE SWEEPING, "COGNIZANCE," AND POLICY

The fact that the new ground mines could not be "swept" by towing wires to sever their mooring cables, because they didn't have any, led to a curious bureaucratic impasse. The Bureau of Ships in charge of minesweeping maintained that since minesweeping was a countermeasure and degaussing was a countermeasure for the new bottom mines, the Bureau of Ships should be in charge of degaussing. The Bureau of Ordnance, on the other hand, maintained that degaussing was in the same class of activity as the provision of armor to ships to withstand the impact of gun projectiles. And they, after all, were in charge of armor. In the meanwhile, the specification of degaussing coils and generators and the measurement of their results on ships was proceeding under extreme urgency - mostly at NOL, under direction of BuOrd. The debate went to CNO and SECNAV who decided that BuOrd would design the degaussing coils and measure the fields and BuShips would install the coils and furnish the power to operate them. This decision was largely predetermined by the fact that BuOrd had already made much progress in the problem and "a change of cognizance in the middle of a project would only result in duplication of effort" - a precept which is sometimes honored and sometimes not.

A second cognizance battle was settled entirely in favor of BuShips. In the first days of the war, the British had found that a magnetic field could be formed to simulate the field from a large ship by passing current in the sea from one electrode to another. As Francis Bitter describes in his book on Magnets (reference (7)) when he arrived in Liverpool in 1940 on an information gathering mission (first NOL representative in the U. K.), "Ships broken in half in the middle lay around the harbor. They were victims of the new ground mines. We also saw the first minesweeping going on. At first we could not understand it. Tugboats were steaming about the harbor dragging enormous black snakes behind them. These were large cables covered with buoyant insulation so they would float. On the tugboats there were powerful motor generators to produce a current. One electrode was at a relatively

7 Bitter, Francis, Magnets, The Education of a Physicist. Garden City, New York, Doubleday, 1959. 
short distance behind the tug, the other at the far end of the (other) cable. A current was made to pass from the distant electrode through the sea water in a rather wide circling path to the forward electrode. This current produced a magnetic field behind the tugboat. The tugboats, therefore, had to be very carefully degaussed because they had to travel over the magnetic mines without exploding them. Then, behind the tugboat were the magnetic fields produced by currents in the sea to imitate the field of a ship.

"This seemed at first a rather odd way of producing a magnetic field. The standard way of doing it is to make a coil. One could make much stronger fields with smaller currents by means of coils of wire, but the problem of making a coi] that could be conveniently towed behind a tugboat was extremely difficult. This was actually a most brilliant solution which made it possible to tow much less wire than would be needed in a coil and to have the wire in an extremely simple form for towing." And I would add, much more resistant or perhaps totally resistant to the dreaded mine explosion when it came. Returning to the cognizance question, the Bureau of Ordnance recommended that the design of influence minesweeping gear be assigned to it in connection with its mine firing design problems. The Bureau of Ships, however, demanded that all sweeping remain under its cognizance, and after much discussion and many conferences the Chief of Naval Operations allowed it to so remain. After all, the towing of electrical cables for magnetic "sweeping" purposes was practically the same as towing mechanical cables for mechanical sweeping purposes.

There is one small irony in connection with this which I cannot refrain from quoting, namely, as Duncan says, "Since the U. S. general policy was opposed to using a mine unless the United States could sweep it, the initial use of several mines was delayed to give the Bureau of Ships the opportunity to develop satisfactory sweeping techniques. Finally, this policy was modified, and toward the end of the war, there were some mines planted in Japanese ports which the United States could not sweep or destroy."

\section{UNITED STATES MINE DEVELOPMENT}

Although the United States duplicated and manufactured replicas of the German magnetic needle mine very early in the war (called Mk 12 Mine), it was at about the same time that the Laboratory initiated the design of several new mines responding to various ship influences, namely, magnetic, acoustic and pressure separately and in combination. Several other possible influences were rejected as less practical, namely, gravitational, optical, cosmic ray and electric potential. These new mines were designed to lie on the bottom, to be launched from aircraft, to contain 500 pounds of high explosive (Mk 36) and another series to contain 1000 pounds of high explosive (Mk 25); and to contain many features like a variety of sensitivity settings, delayed arming, clock and electrolytic sterllizers (so the mine would become a dud after a definite time and would not have to be "swept"), ship counts which would foil what enemy influence sweeping was done. They also contained vacuum tube amplifiers, electrical circuits for differentiating the ship's signals with respect to time so that the maximum could be detected, or indeed a minimum between two maxima or a second maximum. There were many new problems to be solved, not the least of which were what the effect of, say, 1000 pounds of explosive on the bottom would be on a ship of what size and construction at what position in what water depth - and, secondly, what sensitivity to build into the mine so that it would not be triggered prematurely or require the ship to be unnecessarily close. Either of these events 
would reduce the effectiveness of the mine. Finally, how many mines should be laid and in what arrangement, and what is the so-called threat of the resulting mine field as a function of number of mines, and the ratio of sweeping to actual traffic. It should be pointed out that the calculated threat is simply an estimate of the fraction of losses that will be incurred if the enemy chooses to traverse the field. If he chooses not to, then, of course, he has agread to a 100 percent blockade of his traffic. Since he presumably only cares about his ships as items to use - to carry cargo - to move strategically or tactically - the effect of a highthreat mine field is to deprive the other side of the use of his ships, even though he may not lose any. He might as well not have them if he can't use them. All of these points and questions gave rise in the early days of World War II to an evening discussion group at NOL who played "mine warfare games." This was the beginning of "operations research" in this country. The group soon was moved to the CNO, augmented, and named Mine Warfare Operations Research Group (called the "Morgue" for short).

The ground mines, large and small, were started at NOL under direction of BuOrd in 1941 and early 1942 and began to be delivered in quantity in 1944 and 1945. It was these mines which starved the Japanese economy in the last four months of the war. The pressure detecting mechanism was susceptible to wave actuation, but when combined with a magnetic detector so that the mine would ignore either influence except when accompanied by the other, it became virtually unsweepable. The use of this device was not permitted until very late in the war because it was feared that the enemy might learn its secrets and make use of it against the United States and Britain. It turned out, however, that the Germans had a similar device and brought it into use to delay the Allied invasion of Europe in 1944 , first as the famous "Oyster" mine. Our pressure-magnetic mines were then used in large quantities in the final mine attack on Japan in 1945.

\section{ROLE OF U.S. SUBMARINE-LAID MINES IN THE EARLY PACIFIC WAR}

Before discussing the aerial mine attack on Japan, I should mention the role played by the submarine-laid mines Mk 10 and Mk 12 throughout the war, starting in 1941 when 1200 of the former and 600 of the latter were in the mine stockpile.

It will be remembered, the Mk 10 was a moored Hertz horn mine.developed before the war and the Mk 12 was an aluminum-cased magnetic ground mine (a copy of the first German mine recovered in 1939).

Some 100 Mk 10 Mod 3 mines were planted by sub in the Pacific. These were moored magnetic mines with the M-5 magnetic needle mechanism. To solve case motion problems the needle array was in a pair of gimbals and the needle was mechanically compensated by a counterpoise having the same moment of inertia. This too was a copy of the German magnetic moored mine. 
The first mine fields were laid in October 1942 by submarines operating out of Perth, Australia. A total of $160 \mathrm{Mk} 12 \mathrm{mines}$ were laid in approaches to Bangkok, Haiphong, and in the Hainan Strait. These mines immediately sank six ships totaling 22,000 tons and damaged six more, another 18,000 tons. A total of 421 mines in 21 fields sank 27 ships and damaged 27 more throughout the course of the war, or one ship sunk or damaged for every eight mines. This, as we shall see, is a very much better record than for airlaid mines, probably because of the greater accuracy with which mines may be laid in channels by submarines. Of course, submarines take 50 to 100 times longer to traverse a given distance than aircraft and are likely, in the course of this time, to encounter many ships which they can attack with torpedoes (self-propelled modern). If they are lucky, they can sink a ship with one or two torpedoes, whereas it takes eight mines, as we have seen to do it more or less by chance. Conversely, aircraft being on station or in transit are less likely to encounter targets and hence are ideal as minelayers. They can go to the area to be mined at the least risky time, deliver their mines and return home for the most part in safety and comfort. Therefore, it is fairly clear that submarines are useful as mine layers for special missions which are inaccessible to aircraft for one reason or another. Since submarines in World War II generally returned from a period at sea with a few torpedoes unexpended, it became the practice to carry a few mines instead and leave them planted so that the submarine could return empty.

By 1944 the growing availability of the newly developed influence ground mines, and the growing conviction that a mine blockade of Japan would be conclusive, led to concerted efforts on the part of the Navy to find aircraft to be used for minelaying. Naval aircraft (TBFS, PV-1 from carriers, and PBYs) had been used to bottle up lagoons full of Japanese ships, with great effect: viz., several atolls In the Marshall Islands and Palau. However, Navy planes were not large enough to handle payloads of mines over long distances, whereas the Army Air Force B-29's could carry 12 1000-pound mines or seven 2000-pound mines to destinations as much as 1500 miles away (and get back). Continued planning and discussion at all levels, from Admiral Nimitz and General Arnold on down, resulted in the agreement to undertake the aerial mining campaign against Japan. The Navy would furnish the mines and the technical personnel to prepare them plus qualified officers to help plan the operations and brief the pilots. The Navy wanted a complete blockade of Japan's sea lanes in exhange for the use of enough B-29's to do the job. As Lott says (reference (3)), the clinching point was the Navy's statement: "The Air Force will get all the credit." On December 22, 1944 General Arnold issued orders for mining operations to begin the first of April 1945. Once the go-ahead had been given, the Navy moved fast. On January 19, 1945 a group of mine experts arrived in Tinian and one month later they had a mine depot built and in operation for mine assembly. The first mines were actually planted in the Shimonoseki Strait on the night of March 27, 1945, just four days before the assault on Okinawa. It has been said that Operation Starvation was an Alr Force show with a Navy-prepared script. Had it commenced in January, as the Navy wanted, the attrition of enemy shipping would have considerably reduced Japanese resistance by the time of the Okinawa assault.

3 U.S. Strategic Bombing Survey, The Offensive Mine Laying Campaign Against Japan. Washington, reprinted by Dept. of the Navy, Headquarters Naval Material Command, 1969. 
Almost certainly the loss of imports would have brought the Japanese to negotiations which might have prevented Hiroshima and Nagasaki. Lott continues, "Here should be emphasized one of the little-known but highly humanitarian aspects of mine warfare: a mine blockade enables the winner to win without killing. Enemy ships lost in a mine field enter it by their own choice; the enemy is free to keep his ships in port and save them if he wishes. But more important, mines never destroy homes, hospitals, or industrial facilities necessary to peacetime rehabilitation, nor do they wipe out noncombatant civilians."

RESULTS OF OPERATION STARVATION

Let us look briefly at the results of Operation Starvation. Late in 1944, Japan depended on sea traffic from China and Korea to bring in 80 percent of her oil, 88 percent of her iron ore, 24 percent of all coal, 20 percent of her food. Inside the islands, 75 percent of transportation was water-borne. The situation is shown in Figure 10, Japanese Traffic in March 1945, where the width of the lines is proportional to average daily shipping in March 1945. After four and one half months, the situation in August 1945 is shown in Figure 11, Japanese Traffic Situation after Phase 5. During this time, 12,000 mines had been laid by 80 to 100 bombers of the 21st Bomber Command under General LeMay. Aircraft made 1528 trips and delivered 4900 magnetic, 3500 acoustic, 2900 pressure, and 700 low-frequency acoustic mines. The minelaying effort represented 5.7 percent of the 21 st Bomber Command's total effort. (The rest of the effort, about 1500 planes worth, was spent in bombing.) Further data are given in Figure 12, "Starvation Campaign."

\section{SUMMARY OF MINE EFEECTIVENESS IN TWO WORLD WARS}

It is possible very roughly to summarize mine warfare in two world wars in Figure 13. The numbers are hard to pin down; see Duncan (reference (10)) and Johnson (reference 14)). In World War I it took about 45,000 enemy mines to sink or damage beyond repair about 630 allied ships. We have 71 mines per ship. In World War II it took 100,000 U. S. and U. K. mines to sink or damage beyond repair 2665 ships, or 37 mines per ship. Although World War II ships may have been somewhat more seaworthy than World War I ships, we see that mines had become about twice as effective (1.91). This improvement in damage width per mine may be roughly attributed to the increase in charge weight and the effectiveness of aluminized explosive. The damage width would be doubled (1.91) by increasing the 300-pound charge weight to 1200 pounds ( $1110 \mathrm{lb}$.$) . This is perhaps a good average equivalent$ charge weight for all the ground mines used in the war (i.e., $\sim 8001 \mathrm{~b} \times 1.5$ equivalent wt. $=1200 \mathrm{lb}$ ).

\section{POST WWII ERRORS - THE KOREAN SURPRISE}

After World War II, some operation researchers on both sides of the Atlantic decided that all powers would work out their air defenses with modern technology so that no aircraft could fly within reach of harbors or other mineable waters. After all, such aircraft might be carrying atom bombs which would be far too dangerous to let approach. Therefore, there was less use developing air-delivered mines because

10 Duncan, Robert Caruthers, America's Use of Sea Mines. White Oak, Md., U.S. Naval Ordnance Laboratory, 1962.

14 Johnson, Ellis A. and Katcher, David A., Mines Against Japan. White Oak, Md., U.S. Naval Ordnance Laboratory, 1973. 
they could not be delivered. It was concluded that the days of mine warfare were over. In the two succeeding U. S. wars, this conclusion was shown to be premature. In Korea, the U. S. was the recipient of a mining effort which held up our operations at Wonsan for weeks and created a great deal of tension in the process. True, these Russian mines, many of 1904 vintage, were laid by sampan and junk, not by air. Part of the difficulty in sweeping them, apart from the lack of minesweepers and the large number of mines (3000), was that they were laid in a combination of (old) moored and (new) ground mines which presented a new menace to the minesweeper.

\section{THE MINING OF HAIPHONG HARBOR STOPS TRAFFIC}

The operations research conclusions about control of the air did not apply to Vietnam. It was perfectly possible to fly over enemy territory and to drop bombs in an attempt to interdict trails, destroy supply dumps and cut off supplies. It was not until the mining of Haiphong Harbor in May 1972, however, that the movement of supplies into North Vietnam by sea was stopped. Virtually all the ships in the harbor remained there immovable for months, and no new ships came in. The story of the mining of Haiphong, its material, tactics, effectiveness and how the mine blockade was cleaned up has yet to be told. The thin film magnetometer developed at NOL in the sixties widened the variety of munitions which could be used as mines. The magnetometer consisted of a high-frequency oscillator whose frequency shifted measurably when the magnetic field was changed by the presence of a target. This device permitted munitions to be used without parachutes, and reduced the size and power requirements of magnetic detection by a factor of at least 10 . It is indicative of the sagacity of Le Duc Tho in agreeing to a so-called Protocol with $\mathrm{Dr}$. Kissinger on January 27, 1973, in Paris that "the United States agreed to clear all the mines it has placed in the territorial waters, ports, harbors, and waterways of the Democratic Republic of Vietnam. This mine clearing operation shall be accomplished by rendering the mines harmless through removal, permanent deactivation, or destruction." The Vietnamese would render assistance but as part of the "Agreement of Ending the War and Restoring Peace in Vietnam" the U. S. had to agree to clean up the mines!

\section{NEW MINE TECHNOLOGY}

Technology now makes mines so smart that they can compute the difference between a target, a fake, and the background. They can be hidden, can have many sensors and can process the information to a decision - fire, wait, reject. They may be able to be activated on command. They can operate in a wider range of water depth, can be laid by air at low altitude, or by ship or submarine (even by rocket barrage for quick planting in restricted waters). They can be made smaller, more like "ready ammunition" or wooden bombs. They use solid state electronics, computer logic technology, smaller sensors. Their power requirements are minimal; their endurance is correspondingly increased and their resistance to shock is greatly improved. Certain mine combinations are virtually unsweepable and have to be dealt with, if at all, by the costly, laborious, dangerous, and time-comsuming activites of mine hunting and neutralization, i.e., search and destroy missions against mines. This is an uphill fight because mines can be camouflaged; besides that, they are much smaller than their targets and, hence, have an inherent advantage. Further, the cost of mine development, test, production, deployment, training, laying, etc., is small compared with the cost of the rest of the military establishment - possibly between $1 / 100$ and $1 / 1000$ the cost. Mining has become continually more decisive in wars since the first mine was invented. 
If every nation knew the details of every other nation's mines, it would not alter the basic effectiveness of offensive mining which prevents use of the sea either directly or while sweeping and hunting operations are in progress. The possession of offensive and defensive mines by any nation gives that nation a great advantage in war. If warring nations use mines, they will block each other and prevent the movement of goods of any sort by sea (or by land if these principles are extended to land warfare). This simply means that the development of technology in mine warfare is making limited warfare obsolete, just as nuclear weapons have made all-out warfare obsolete. If the human race is going to continue to have warfare, it will have to use less effective weapons! If they cost a lot more, so much the better - there will then be fewer of them and hence the risk will be decreased. But until that day, the United States had better be prepared to wage offensive and defensive mine warfare should the need arise. 


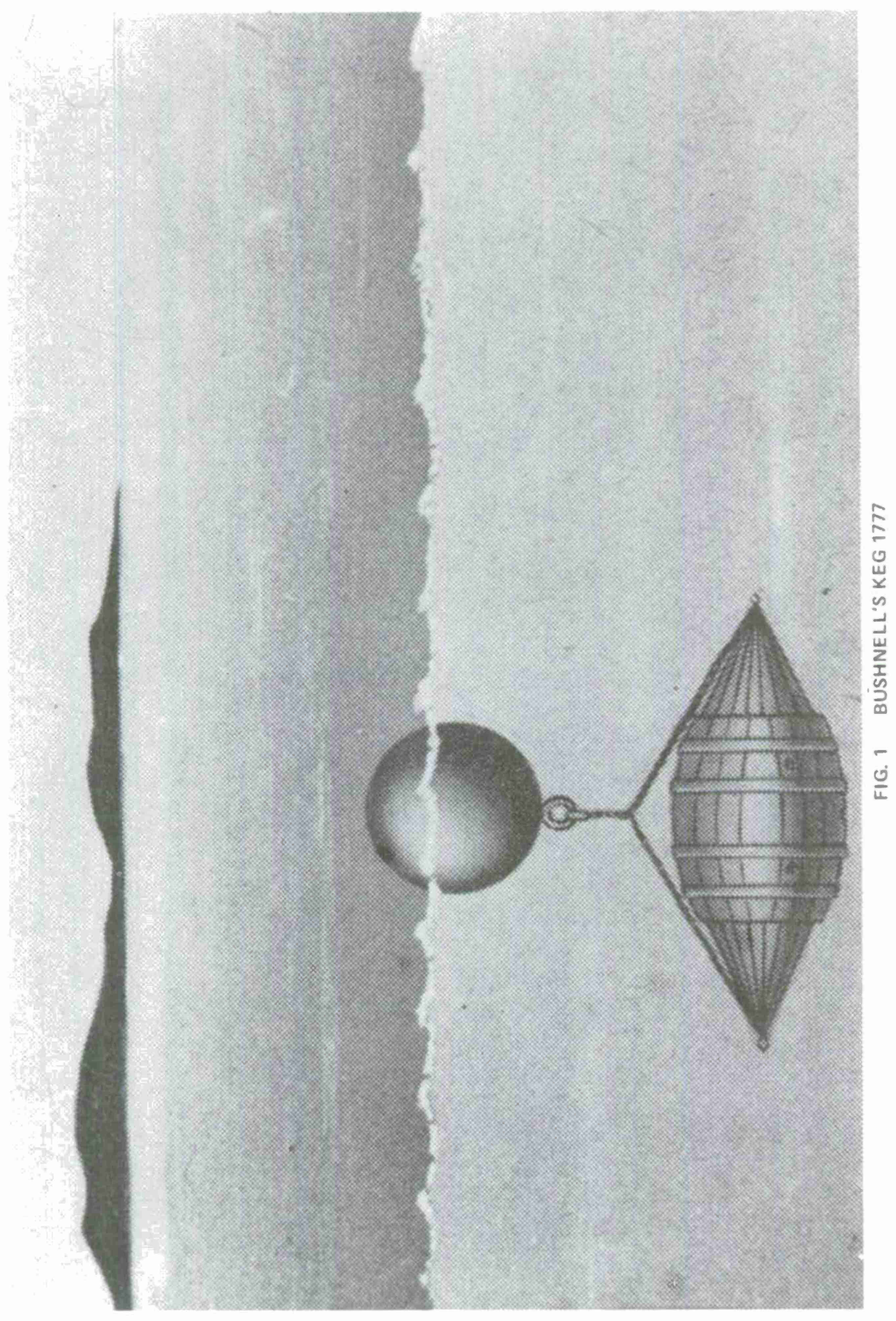




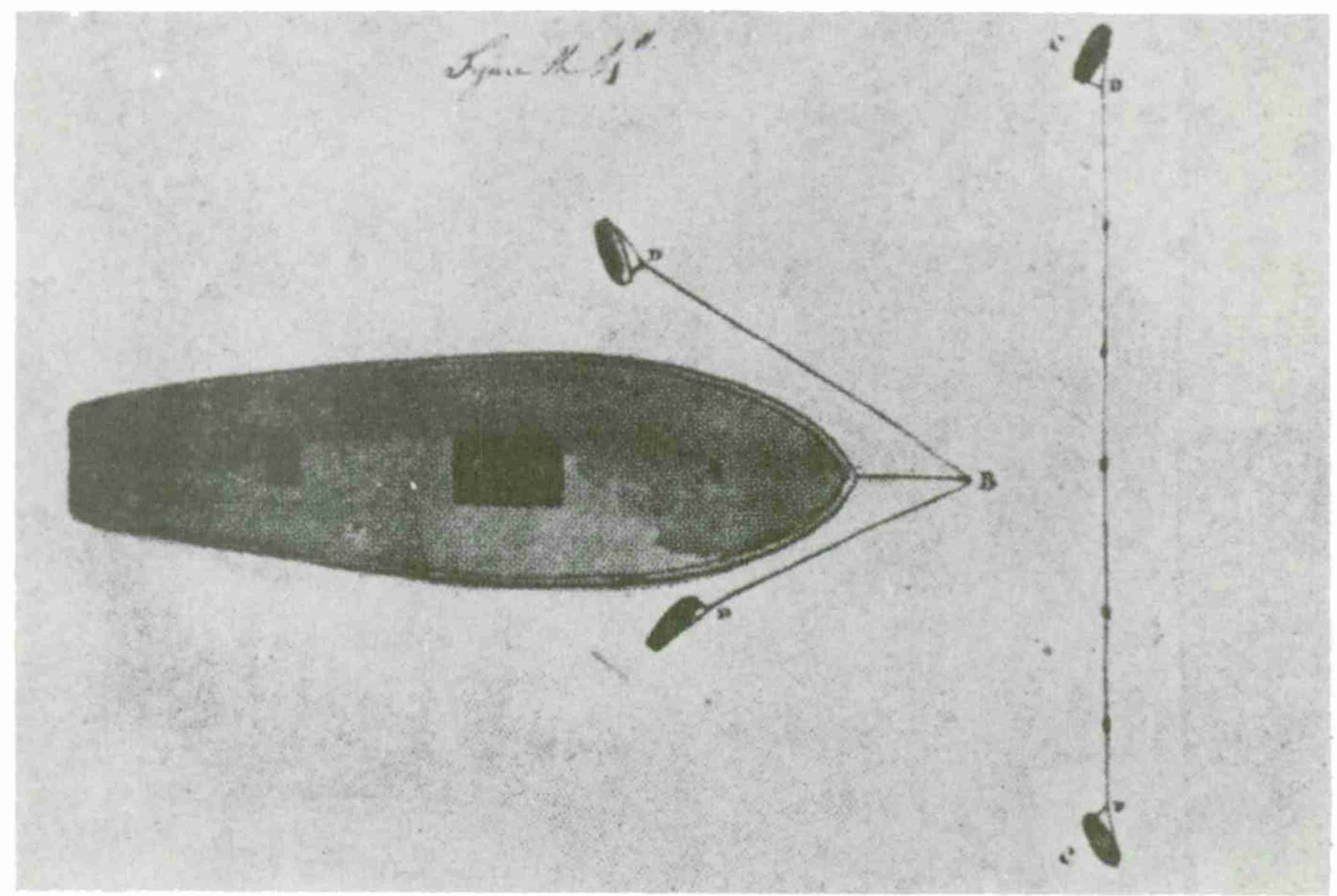

FIG. 2 USE OF DRIFTING MINES (AS SKETCHED BY ROBERT FULTON 1806) 


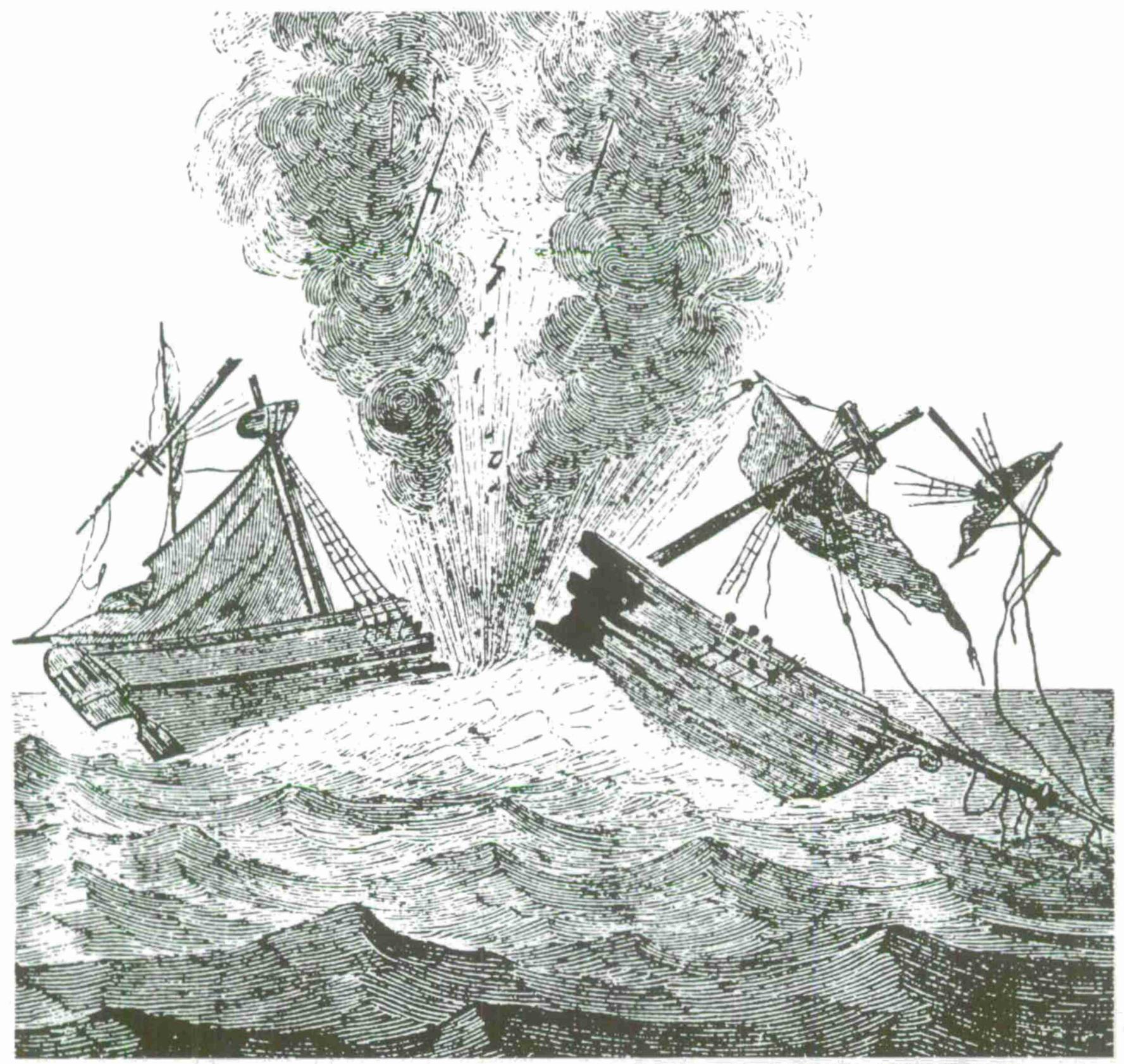

FIG. 3 DEMOLITION OF THE BRIG DOROTHEA (AS SKETCHED BY ROBERT FULTON 1805) 


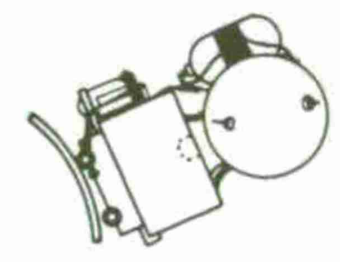

MINE IS LAUNCHED

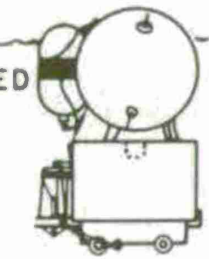

MINE STABILIZES TSELF AND FLOATS FOR 6-10 SECONDS

\section{DASHPOT ALLOWS} PLUMMET TO FALL

c

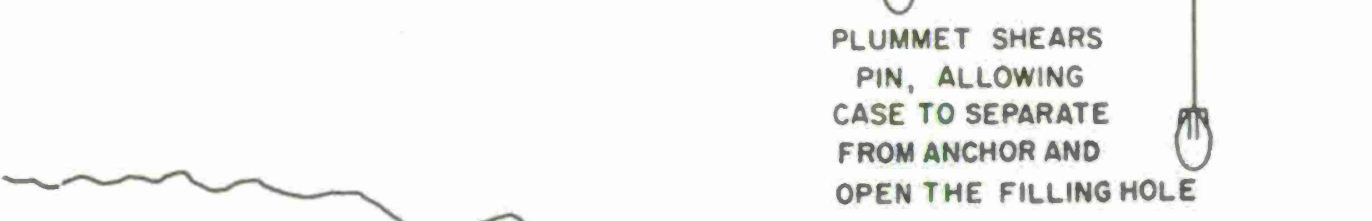

ANCHOR SINKS,

PAYING OFF MOORING

CABLE UNTIL PLUMMET

STRIKES BOTTOM,

CABLE DRUM LOCKS

FIG. 4 MINE MARK 6 PLANTING SEQUENCE
ANCHOR CONTINUES

TO SINK, PULLING

CASE BELOW SURFACE,

UPPER ANTENNA IS

RELEASED AND

STREAMS OUT 


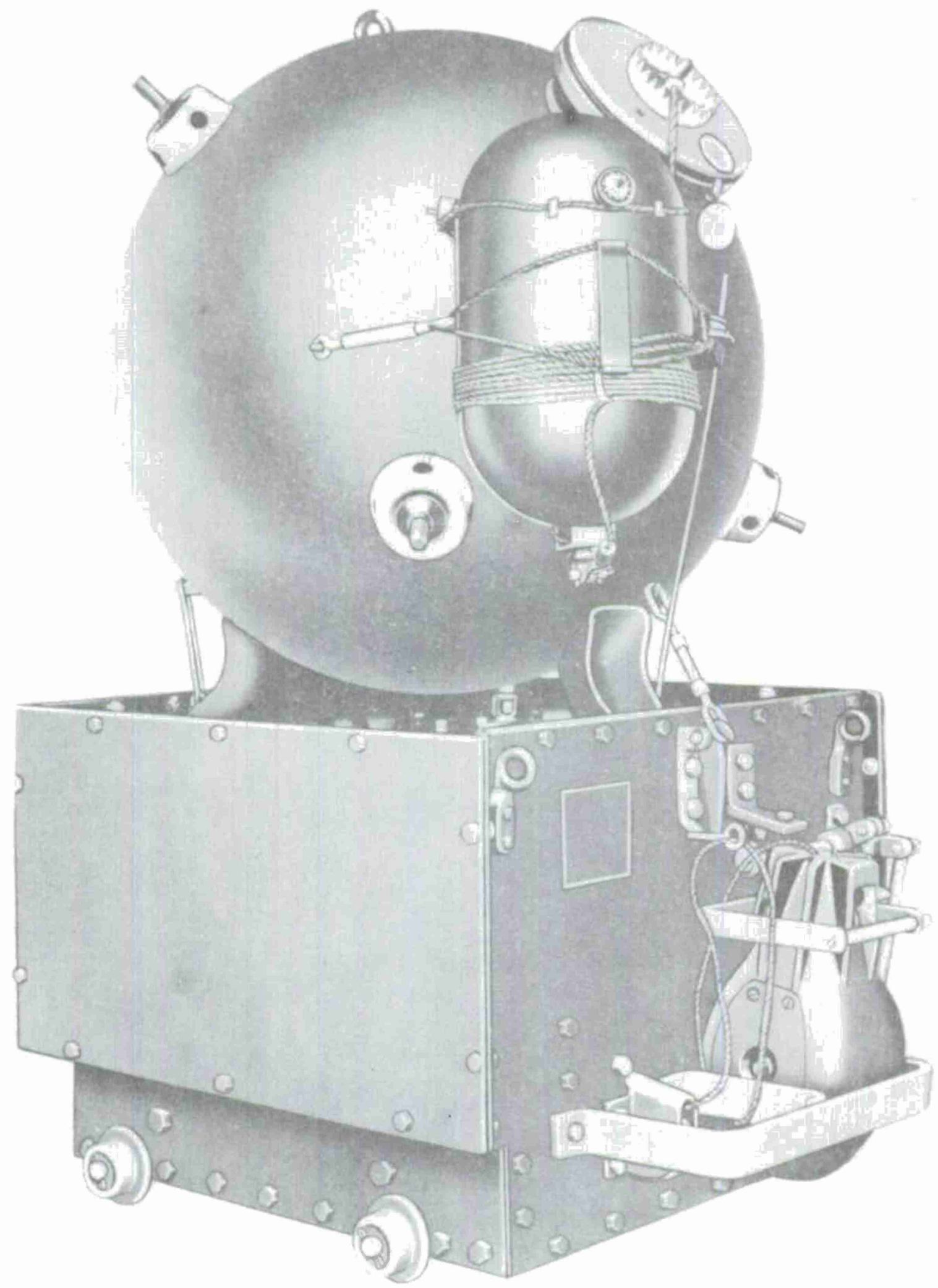

FIG. 5 MINE MARK 6 

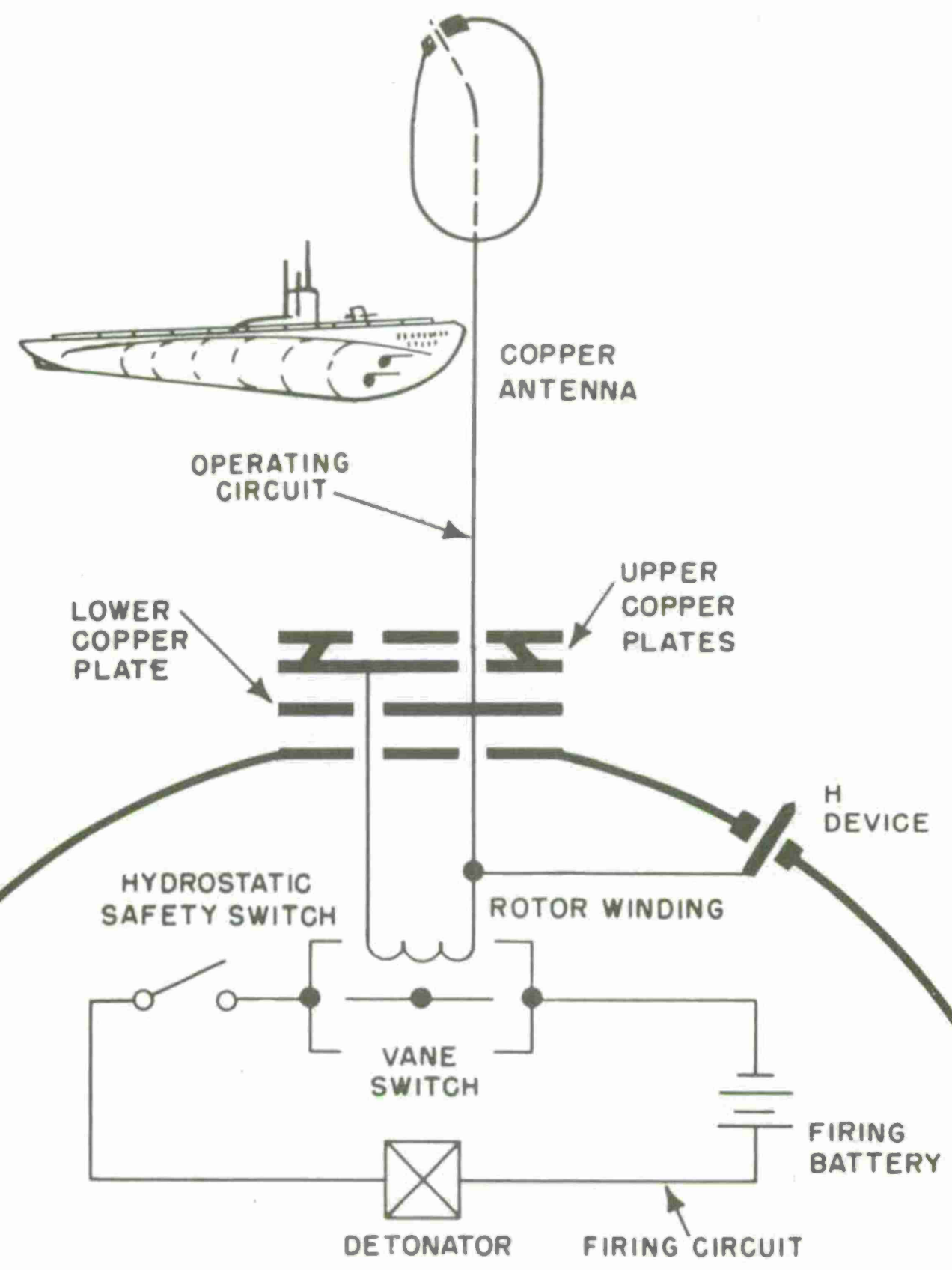

ANTENNA

FIG. 6 CIRCUITS OF THE K-DEVICE 

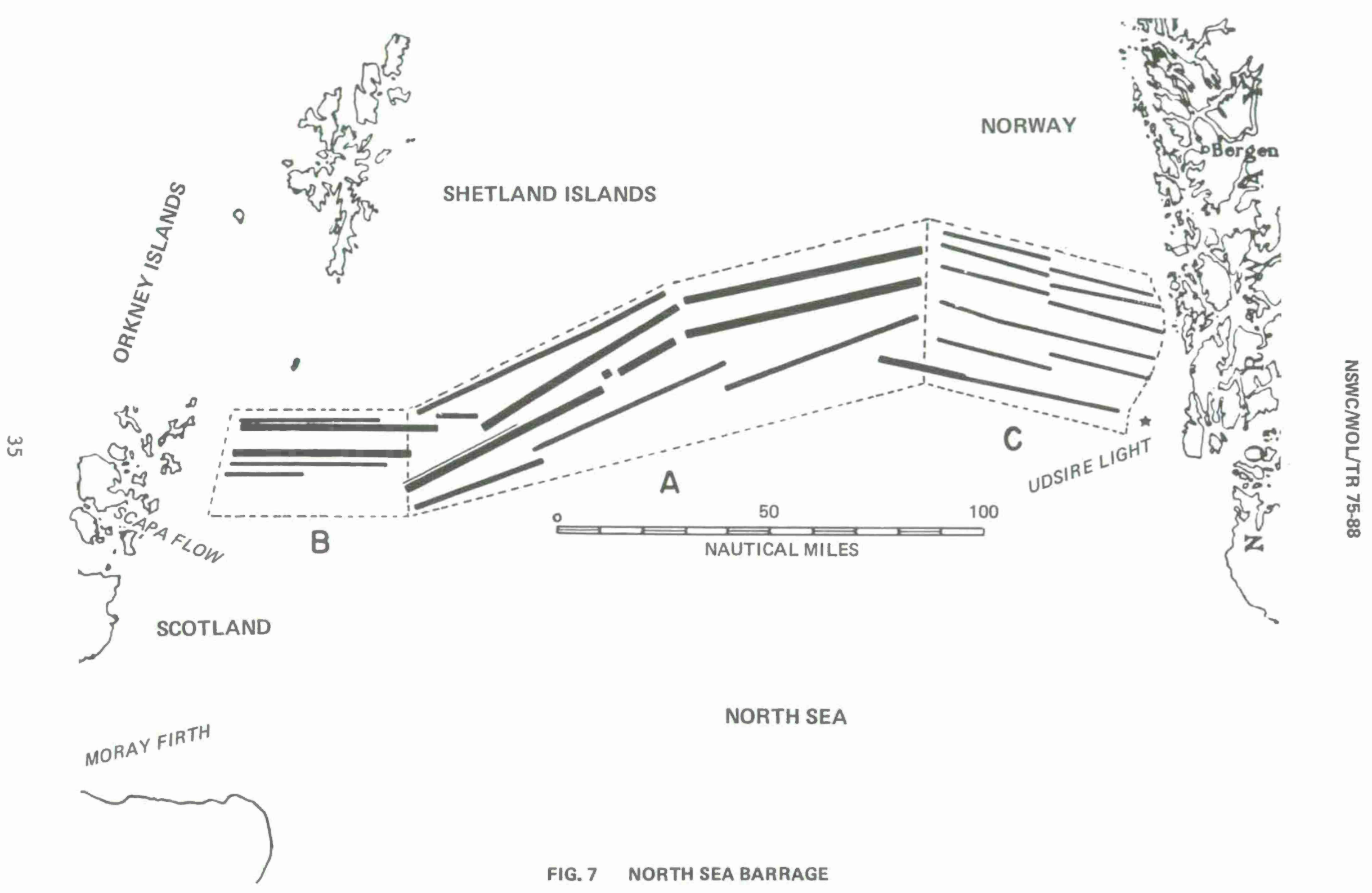

NORTH SEA

FIG. 7 NORTH SEA BARRAGE 


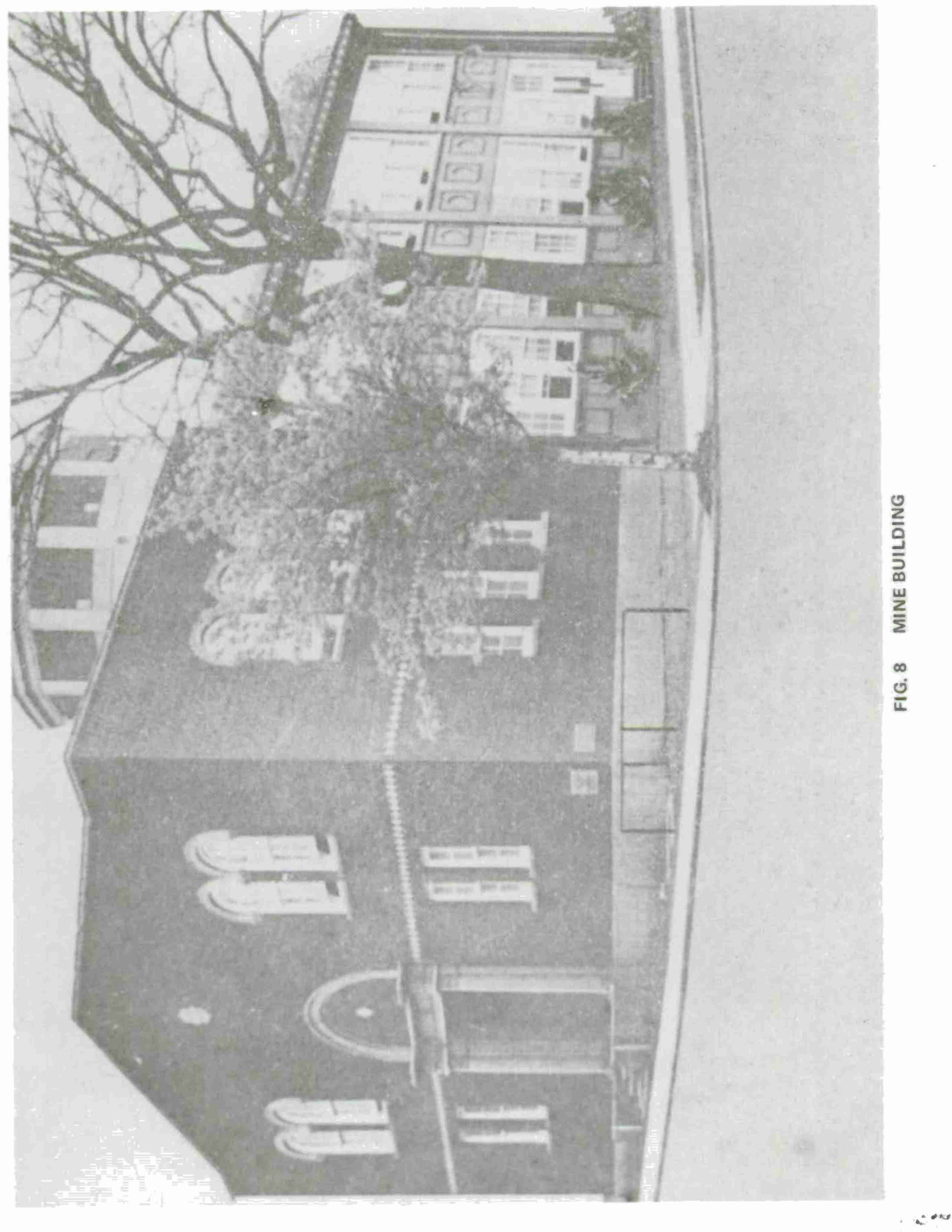




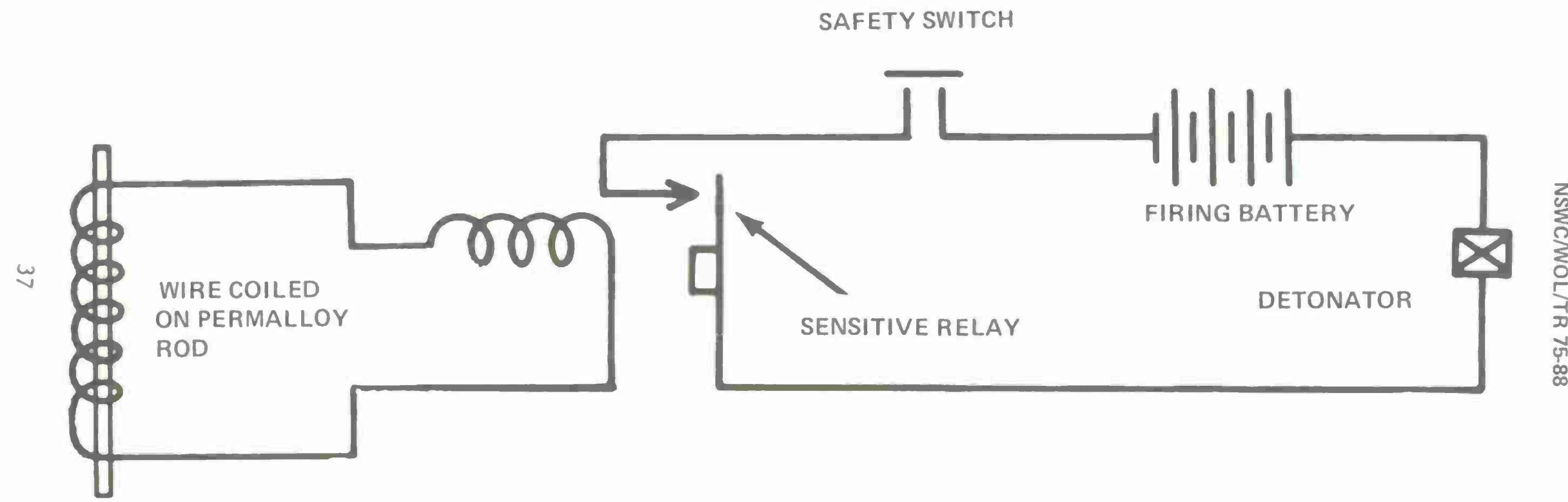

FIG. 9 FUNCTIONAL DIAGRAM OF INDUCTION TYPE MAGNETIC MINES 


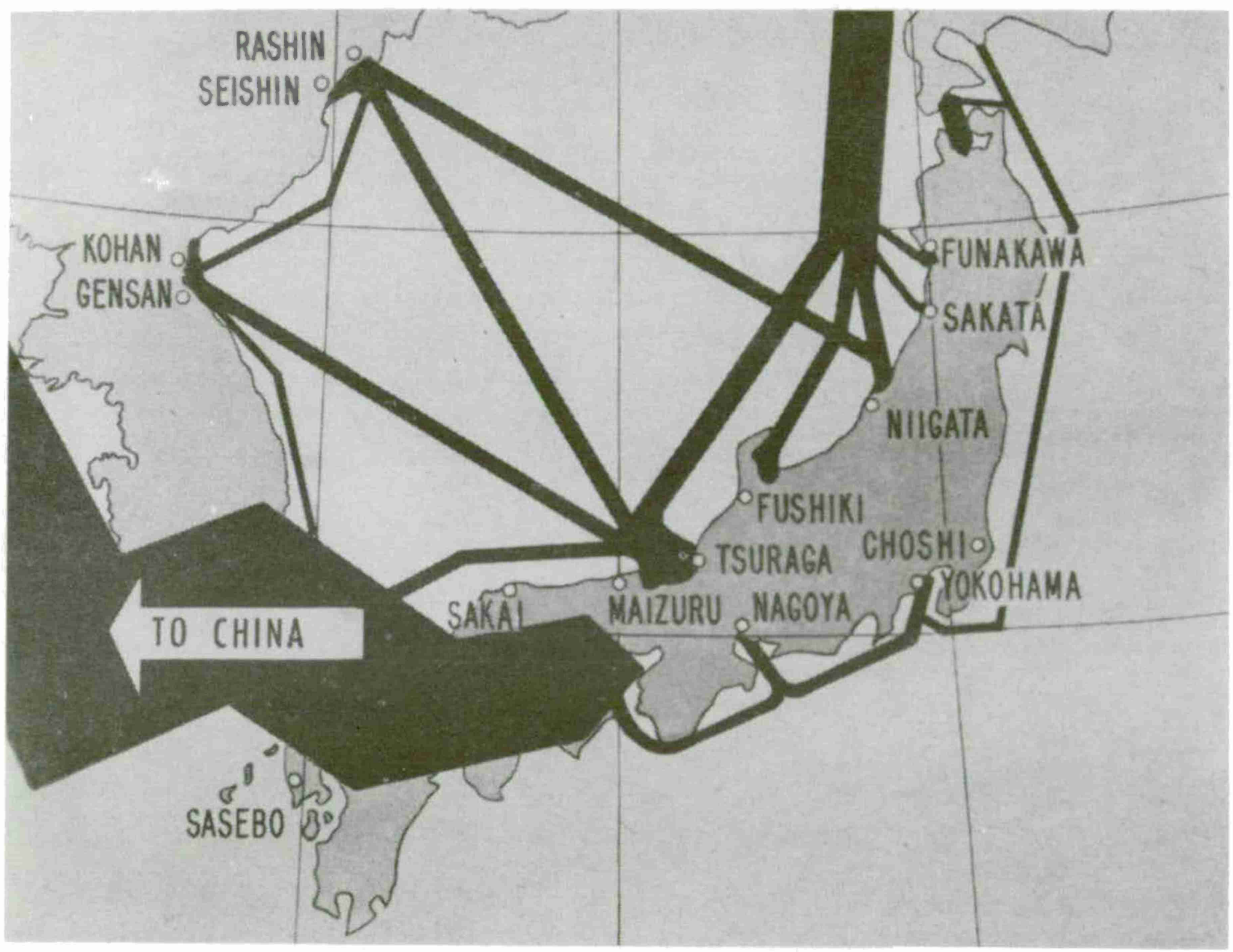




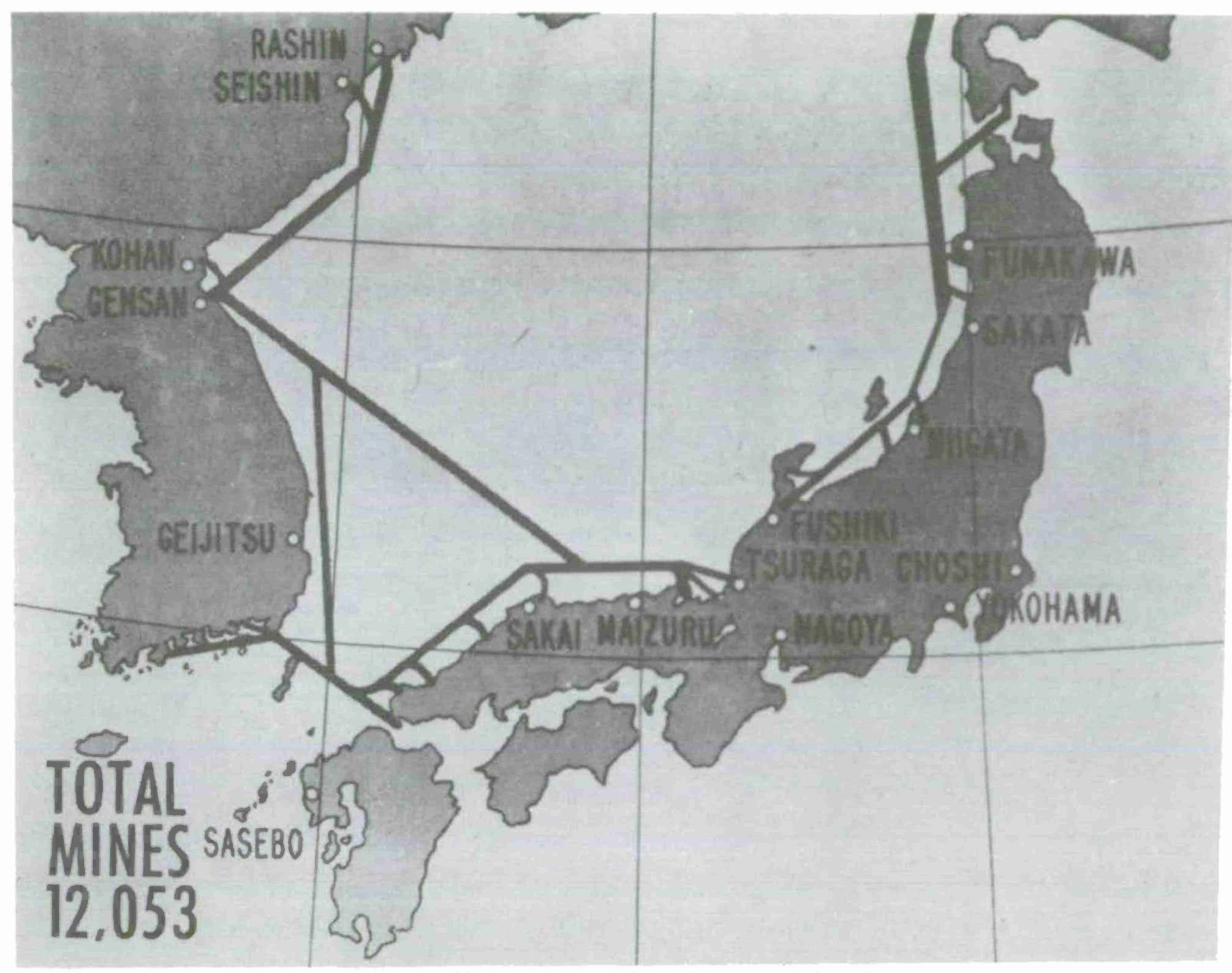




\begin{tabular}{c|c|c|c|c|c}
$\begin{array}{c}\text { MINES } \\
\text { LAID }\end{array}$ & $\begin{array}{c}\text { SORTIES } \\
\text { FLOWN }\end{array}$ & $\begin{array}{c}\text { PLANES LOST } \\
\text { (FEW BY ENEMY } \\
\text { ACTION) }\end{array}$ & $\begin{array}{c}\text { SHIPS } \\
\text { SUNK }\end{array}$ & $\begin{array}{c}\text { DAMAGED BEYOND } \\
\text { REPAIR }\end{array}$ & $\begin{array}{c}\text { DAMAGED AND } \\
\text { REPAIRED }\end{array}$ \\
12,026 & 1,528 & 15 & 24 & 137 & 239
\end{tabular}

$$
\begin{aligned}
8 & \text { MINES LAID PER SORTIE } \\
431 & \text { SHIPS LOST OR } 900,000 \text { TONS } \\
9,000 & \text { TONS OF MINE PAYLOAD } \\
100 & \text { TONS OF SHIPPING LOST FOR EACH } \\
& \text { TON OF MINES LAID } \\
29 & \text { SHIPS LOST FOR EACH PLANE LOST } \\
31 / 2 & \text { SORTIES FOR EACH SHIP LOST } \\
28 & \text { MINES LAID FOR EACH SHIP LOST }
\end{aligned}
$$

\begin{tabular}{|c|c|c|c|c|}
\hline & $\begin{array}{l}\text { TOTAL MINES } \\
\text { LAID }\end{array}$ & $\begin{array}{l}\text { OFFENSIVE MINES } \\
\text { LAID }\end{array}$ & SHIPS LOST & $\begin{array}{l}\text { OFFENSIVE MINES LAID } \\
\text { PER SHIP LOST }\end{array}$ \\
\hline WWI & 240,000 & 45,000 a $/$ & 630 b/ & 71 \\
\hline WW II & $300,000 \underline{c} /$ & 100,000 c $/$ & $2,665 \mathrm{~d} /$ & 37 \\
\hline
\end{tabular}

FIG. 12 STARVATION CAMAIGN APRIL-AUGUST 1945
a. CENTRAL POWERS ONLY
b. ALLIED LOSSES
c. U.S. AND U.K. ONLY
d. JAPANESE AND AXIS POWERS ONLY

FIG. 13 MINE WARFARE IN TWO WORLD WARS 


\section{BIBL IOGRAPHY}

1. Mahan, Alfred Thayer, The Influence of Sea Power Upon History, 1660-1783. Boston, Little, Brown and Company, 1890.

2. U.S. Office of Naval Records and Library, "The Northern Barrage and Other Mining Activities". Pub. under the direction of the Hon. Josephus Daniels, Secretary of the Navy. Washington, Gov't. Printing office, 1920.

3. U.S. Strategic Bombing Survey, The Offensive Mine Laying Campaign Against Japan. Washington, reprinted by Dept. of the Navy, Headquarters Naval Material Command, 1969 .

4. Morison, Samuel Eliot, The Battle of the Atlantic, September 1939 - May 1943. Vol. 1, Boston, Little, Brown and Company, 1947.

5. Peck, Taylor, Round-shot to Rockets; A History of the Washington Navy Yard and U.S. Naval Gun Factory. Annapolis, United States Naval Institute, 1949.

6. Cowie, J.S., Mines, Minelayers and Minelaying. London, New York, Oxford Univ. Press, 1949.

7. Bitter, Francis, Magnets, The Education of a Physicist. Garden City, New York, Doubleday, 1959.

8. Lott, Arnold S., Most Dangerous Sea; A History of Mine Warfare and an Account of U.S. Navy Mine Warfare Operations in World War II and Korea. Annapolis, U.S. Naval Institute, 1959.

9. Richardson, Lewis Fry, Statistics of Deadly Quarrels, edited by Quincy Wright and C. C. Lienau, Pittsburgh, Boxwood Press, 1960.

10. Duncan, Robert Caruthers, America's Use of Sea Mines. White Oak, Md., U.S. Naval Ordnance Laboratory, 1962.

11. Tuchman, Barbara, The Guns of August. New York, MacMillan and Company, 1962.

12. Winters, Albim and Patterson, "A Brief History of Mine Warfare", unpublished.

13. Meacham, James A., Cdr., "Four Mining Campaigns: An Historical Analysis of the Decisions of the Commanders". Naval War College Review, Vol. XIX, No. 10, June 1967 .

14. Johnson, Ellis A. and Katcher, David A., Mines Against Japan, White Oak, Md., U.S. Naval Ordnance Laboratory, 1973. 



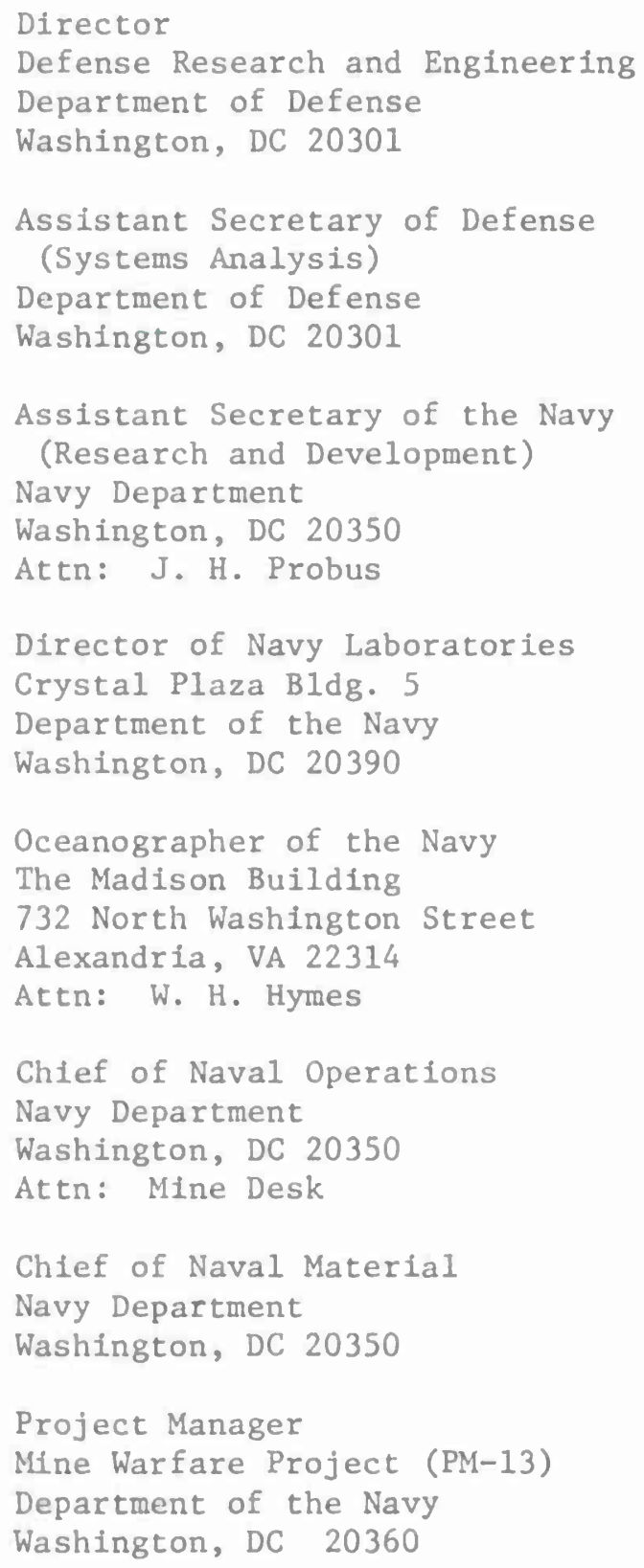

Project Manager

Mine Warfare Project (PM-13)

Department of the Navy

Washington, DC 20360 
Chief of Naval Personnel

Department of the Navy

Washington, DC 20370

Chief of Naval Research

800 North Quincy Street

Arlington, VA 22217

Attn: Chief Scientist (ONR-102)

Commander

Naval Air Systems Command

Washington, DC 20360

Attn: AIR-530

AIR-5305A (L. E. Wheat)

Commander

Naval Electronic Systems Command

Washington, DC 20360

Commander

Naval Sea Systems Command

Washington, DC 20360

Director and Chief

Center for Naval Analyses

1401 Wilson Boulevard

Arlington, VA 22209

Attn: Dr. J. R. Pipal

Project Manager

Deep Submergence Systems Project

Department of the Navy

6900 Wisconsin Avenue

Chevy Chase, MD 20015

officer in Charge

Strategic Analysis Support Group

Applied Physics Laboratory

Silver Spring, MD 20910

Director

Strategic Systems Project Ofrice

Washington, DC 20390

Commander in Chief

Headquarters, U. S. Air Force

Washington, DC 20330 
Commander in Chief

DOX, Headquarters SAC

Offutt Air Force Base

Nebraska 68113

Commander

Army Materiel Command

Washington, DC 20315

Director

Army Mobility Equipment

Research and Development Center

Fort Belvoir, VA 22060

Commanding General

Army Munftions Command

Picatinny Arsena1, Bldg 62N

Dover, NJ 07801

Commandant

U. S. Coast Guard

400 Seventh Street, SW

Washington, DC 20591

Commanding General, Marine Corps

Development and Education Command

(Mobility and Support Division)

Quantico, VA 22134

Director

Applied Physics Laboratory

University of Washington

Seattle, WA 98105

Attn: Undersea Warfare Research

and Development Planning Council

Commandant

U. S. Army Engineer School

Combat and Training Development

Concepts and Studies Division

Fort Belvoir, VA 22060

Director

National Academy of Sciences

2101 Constitution Avenue, NW

Washington, DC 20418 
Director

Ordnance Research Laboratory

Pennsylvania State University

State College, PA 16801

Attn: Undersea Warfare Research

and Development Planning Council

Director

Scripps Institute of Oceanography

P.0. Box 1529

La Jolla, CA 92037

Attn: Undersea Warfare Research and

Development Planning Council

Director

Defense Advanced Research

Projects Agency/TTO

1400 Wilson Boulevard

Arlington, VA 22209

Director

Woods Hole Oceanographic

Institute

Woods Hole, MA 02543

Attn: Undersea Warfare Research and

Development Planning Council

Superintendent, Naval Academy

Annapolis, MD 21402

Superintendent

Naval Postgraduate School

Monterey, CA 93940

Commanding officer

Naval School Explosive Ordnance

Disposal

Indian Head, MD 20640

Commanding officer

Fleet and Mine Warfare Training Center

Charleston, SC 29408

Commanding officer

Naval Training Device Center

Orlando, FL 32813

President

Naval War College

Newport RI 02840 
Commandant

National War College

Washington, DC 20305

Commanding officer, Naval Reserve

Officer Corps Training Unit

University of Kansas

Lawrence, KS 66044

Director of Central Intelligence

Washington, DC 20505

Director

Defense Intelligence Agency

Washington, DC 20301

Commander, Naval Air Development

Center, Johnsville

Warminster, PA 18974

Undersea Warfare Research and

Development Planning Council

Commanding officer

Naval Ammunition Depot

Colts Neck, NJ 07722

Commanding officer

Naval Ammunition Depot

Hawthorne, NV 89415

Commanding officer

Naval Ammunition Depot

FPO San Francisco 96612

Commanding officer

Naval Civil Engineering Laboratory

Port Hueneme, CA 93043

Commander

Naval Electronics Laboratory Center

San Diego, CA 92152

Attn: Undersea Warfare Research and Development Planning Council

Comnanding officer

Naval Explosive Ordnance Disposal

Facility

Indian Head, MD 20640 
officer in Charge

Naval Mine Engineering Facility

Yorktown, VA 23491

Commander

Naval Oceanographic office

Washington, DC 20390

Undersea Warfare Research and Development Planning Council

Commanding Officer

Naval Ordnance Station

Louisville, KY 40214

Commanding officer

Naval Ordnance Systems Support office, Atlantic

Bldg. 62, Norfolk Naval Shipyard

Portsmouth, VA 23709

Commanding officer

Naval Personnel Research and

Development Laboratory

Bldg. 200, Washington Navy Yard

Washington, DC 20390

Director

Naval Research Laboratory

Washington, DC 20375

Attn: Undersea Warfare Research and

Development Planning Council

Commander, Naval Safety Center

Naval Air Station

Norfolk, VA 23511

Commanding officer

Naval Intelligence Support Center

4301 Suitland Road

Washington, DC 20390

Commander

Naval Ship Engineering Center

Prince George's Center

Hyattsville, MD 20782 
Commander

Naval Ship Research and

Development Center

Bethesda, MD 20034

Attn: Undersea Warfare Research and Commander

Development Planning Council

Commanding officer

Naval Ship Research and

Development Center

Annapolis, MD 21402

Commanding officer

Naval Coastal Systems Laboratory

Panama C1ty, FL 32401

Attn: G. Gould

Undersea Warfare Research and

Development Planning Council

Commanding officer

Naval Torpedo Station

Keyport, WA 98345

Commander

Naval Undersea Center

San Diego, CA 92132

Attn: Undersea Warfare Research and Development Planning Council

Commanding officer

Naval Underwater Systems Center

Newport, RI 02840

Attn: Undersea Warfare Research and

Development Planning Council

Commander

Naval Undersea Center

3202 E. Footh1ll Boulevard

Pasadena, CA 91107

Commander

Naval Weapons Center

China Lake, CA 93555 
Commanding officer

Naval Weapons Station

Yorktown, VA 23491

Officer in Charge

Navy Tactical Doctrine Activity

Washington Navy Yard

Washington, DC 23090

Defense Documentation Center

Cameron Station

Alexandria, VA 22314

Commander in Chief

U. S. Naval Forces, Europe

FPO New York 09510

U. S. Liaison Officer to Supreme Allied Commander, Atlantic

Norfolk, VA 23511

U. S. National Military Representative

Supreme Headquarters

Allied Powers, Europe

APO New York 09055

Attn: US DOCO

Commander in Chief

U. S. Atlantic Fleet

Norfolk, VA 23511

Commander Second Fleet

Norfolk, VA 23511

Commander Sixth Fleet

FPO New York 09501

Commander Seventh Fleet

FPO San Francisco 96601

Commanding Officer

Fleet Intelligence Center, Atlantic

Norfolk, VA 23511 
Commanding officer

Fleet Intelligence Center, Europe

Box 18, Naval Air Station

Jacksonville, FL 32212

Commanding officer

Fleet. Weather Facility

Washington, DC 20390

Commander in Chief

U. S. Pacific Fleet

FPO San Francisco 96610

Commander, Amphibious Training

Command, U. S. Atlantic Fleet

Naval Amphibious Base, Little Creek

Norfolk, VA 23521

Commander Amphibious Force

U. S. Atlantic Fleet

Norfolk, VA 23520

Commander Antisubmarine Warfare Force

U. S. Atlantic Fleet

Norfolk, VA 23511

Commanding General

Fleet Marine Force, Atlantic

Norfolk, VA 23511

Commander

Mine Warfare Force, U. S. Navy

Charleston, SC 29408

Commander

Mine Warfare Command, U. S. Navy

Charleston, SC 29408

Commander Naval Air Force

U. S. Atlantic Fleet

Naval Air Station

Norfolk, VA 23511

Commander Operational Test and

Evaluation Force

Norfolk, VA 23511 
Comnander Service Force

U. S. Atlantic Fleet

Norfolk, VA 23511

Commander Submarine Force

U. S. Atlantic Fleet

Norfolk, VA 23511

Commander, Naval Inshore

Warfare Command, Atlantic

Naval Amphibious Base, Little Creek

Norfolk, VA 23521

Commander Submarine

Development Group 2, Box 70

Naval Submarine Base, New London

Groton, CT 06340

Commander, Carrier Division 2

FPO New York 09501

Commander, Carrier Division 4

FPO New York 09501

Commander, Carrier Division 6

FPO New York 09501

Commander Mine Squadron 10

U. S. Atlantic Fleet

FPO New York 09501

Commander Submarine Squadron 4

U. S. Atlantic Fleet

FPO New York 09501

Commander Fleet Air Wings/Fleet Air Wing 5

Naval Air Station

Brunswick, ME 04011

Commander Fleet Air Wing 11

Box 34, Naval Air Station

Jacksonville, FL 32212

Commander, Nuclear Weapon

Training Group, Pacific

Naval Air Station, North Island

San Diego, CA 92135 
Commander Hawaiian Sea Frontier

Box 110

FPO San Francisco 96610

Commander Western Sea Frontier

Treasure Island

San Francisco, CA 94130

Commander Amphibious Force

U. S. Pacific Fleet

San Diego, CA 92155

Commander

Antisubmarine Warfare Force

U. S. Pacific Fleet

FPO San Francisco 96610

Commander Naval Air Force

U. S. Pacific Fleet

Box 1210, Naval Air Station

San Diego, CA 92135

Commander, U. S. Naval Forces, Japan

FPO Seattle 98762

\section{Commander}

U. S. Naval Forces, Korea

APO San Francisco 96301

Deputy Commander Operational Test and Evaluation Force, Pacific

Naval Air Station, North Island

San Diego, CA 92135

Commander Service Force

U. S. Pacific Fleet

FPO San Francisco 96610

Comnander Submarine Force

U. S. Pacific Fleet

FPO San Francisco 96610

Commander

U. S. Taiwan Patrol Force

U. S. Pacific Fleet

FPO Seattle 98770 


\section{DISTRIBUTION LIST (Cont.)}

Copies

Commander Carrier Division 1

FPO San Francisco 96601

Commander Carrier Division 3

FPO San Francisco 96601

Commander Carrier Division 5

FPO San Francisco 96601

Commander Carrier Division 7

FPO San Francisco 96601

Commander Mine Flotilla 3

U. S. Pacific Fleet

FPO San Francisco 96601

Commander Amphibious Group 1

FPO San Francisco 96601

Commander Submarine Squadron 1

FPO San Francisco 96601

Commander Fleet Air Wing 1

FPO Seattle 98768

Commander Fleet Air Wing 2

FPO San Francisco 96601

Commander Fleet Wing 10

FPO San Francisco 96601

Director

Institute for Defense Analyses

400 Army-Navy Drive

Arlington, VA 22202

Chief of Research and Development

Department of the Army

Washington, DC 20315

Commander Army Materiel Systems Analysis Agency

Aberdeen Proving Ground, MD 21005

Commandant

Armed Forces Staff College

Norfolk, VA 23511 


\section{DISTRIBUTION LIST (Cont.)}

Commandant Industrial College

of the Armed Forces

Fort Lesley J. McNair

Washington, DC 20315

Chief of Naval Air Reserve

Naval Air Station

Glenview, IL 60026

Officer in Charge

Naval Air Reserve

ASW Tactical School

Naval Air Station

Willow Grove, PA 19090

Commanding officer

Naval Air Reserve

Naval Air Station

Alameda, CA 94501

Commanding officer

Naval Air Reserve Unit

Naval Air Facility

Washington, DC 20390

Commanding officer

Naval Amphibious School, Little Creek

Naval Amphibious Base

Norfolk, VA 23521

Commanding Officer and Director

Atlantic Fleet ASW TActical School

Norfolk, VA 23511

Commanding officer

Fleet Anti-Submarine Warfare School

San Diego, CA 92147

Director Naval Weapons

Engineering Support Activity

Washington Navy Yard

Washington, D.C. 20390

Commandant

lst Naval District

495 Summer St.

Boston, MA 02210 
Commandant

3rd Naval District

Flushing and Washington Aves.

Brooklyn, NY 11251

Commandant

4th Naval District

Philadelphia, PA 19112

Commandant

5 th Naval District

Norfolk, VA 23511

Commandant

6th Naval District

Naval Base

Charleston, SC 29408

Commandant

8th Naval District

New Orleans, LA 70146

Commandant

9 th Naval District

Building 1

Great Lakes, I1 60088

Commandant

10th Naval District

FPO New Yrok 09551

Commandant

11th Naval District

San Diego, CA 92132

Commandant

12th Naval District

Treasure Island, Building 1

San Francisco, CA 94130

Commandant

13th Naval District

Seattle, WA 98115

Commandant

14th Naval District

Box 110

FPO San Francisco 96610 
Commandant

15th Naval District

FPO New York 09580

Commandant

Naval District Washington

Washington Navy Yard

Washington, DC 20390

Aeroject Electro Systems Co.

P. O. Box 296

Azusa, CA 91702

Attn: R. H. Iketani

G. E. Kern

Aeroject Manufacturing Co.

1120 Conn. Avenue, NW

Washington, DC 20036

Atnt: R. R. Bradley

J. P. Stopper

Applied Research Laboratories

The University of Texas at Austin

P. 0. Box 8029

Austin, TX 78712

Attn: Dr. C. M. McKinney

B. F. Weiss

ARINC Research Corporation

2551 Riva Road

Annapolis, MD 21401

Attn: F. C. Townley

Automation Industries, Inc.

Vitro Laboratories Division

14000 Georgia Avenue

Silver Spring, MD 20910

Attn: CAPT N. B. Atkins, USN(Ret)

Bendix Corporation

Electrodynamics Division

11600 Sherman Way

North Hollywood, CA 91605

Attn: F. Geldert 
Bendix Corporation

$1730 \mathrm{~K}$ Street, NW

Washington, DC 20006

Attn: F. L. Lundquist

Burroughs Corporation

P. 0. Box 517

GVL - DS\&SSG

Paoli, PA 19301

Attn: R. M. Tillman

Booz-Allen Applied Research, Inc.

4733 Bethesda Avenue

Bethesda, MA 20014

Attn: C. F. Willard

CELESCO Industries, Inc.

2001 Jefferson Davis Highway

Arlington, VA 22202

Attn: S. F. McMurray

CELESCO Industries, Inc.

3333 Harbor Boulevard

Costa Mesa, CA 92626

Attn: COL J. D. Blanchard, USAF(Ret)

Delco Electronics

Santa Barbara Operations

6767 Hollister Avenue

Goleta, CA 93017

Attn: A. M. Pederson

Edo Corporation

13-10 111th Street

College Point, NY 11356

Attn: S. Roman

Edo Corporation

2001 Jefferson Davis Highway

Arlington, VA 22202

Attn: R. N. Flath

General Electric Company

P. 0. Box 1122

Farrell Road Plant, Bldg 1, Rm M8

Syracuse, NY 13201

Attn: F. G. Spann 
Goodyear Aerospace Corporation

1210 Massillon Drive

Akron, $\mathrm{OH} 44315$

Attn: W. F. Johnson

Gould, Inc.

Advanced Technology Group

18901 Euclid Avenue

Cleveland, OH 44117

Attn: T. E. Lynch

Harry Diamond Laboratories

(AMXDO-SAB)

Washington, DC 20438

Attn: M. B. Ginsberg

Honeywell, Inc.

600 N. 2nd Street

Hopkins, MN 55343

Attn: J. O. Voss

I. E. DuPont De Nemours \& Co. Inc.

Wilmington, DE 19898

Attn: L. M. Magner

Lockheed Ocean Laboratory

3380 N. Harbor Drive

San Diego, CA 92101

Attn: RADM L. D. Coates, USN(Ret)

Lockheed Missile and Space Company

1111 Lockheed Way

P. 0. Box 504

Sunnyvale, CA 94088

Attn: C. P. Sherburne

Presearch, Inc.

8720 Georgia Avenue

Silver Spring, MD 20910

Attn: G. L. Brubaker

T. C. Cox

J. R. Penny

CAPT D. E. Hihn, USN(Ret)

Quality Evaluation and

Engineering Laboratory

Naval Ammunition Depot

FPO San Francisco 96612

Attn: H. H. Meeker, Jr. 
The Rand Corporation

1700 Main Street

Santa Monica, CA 90406

Attn: Dr. M. M. Balaban

J. W. Higgins

Dr. J. E. Neufer

Government Plans and

Systems Development

RCA Corporation (108-113)

Borton Landing Road \& Marne Highway

Moorestown, NJ 08057

Attn: BGEN F. P. Henderson, USMC (Ret)

Leland Stanford Junior University

Stanford University

7100 Serra Street

Stanford, CA 94305

Attn: Drw D. B. DeBra

Thiokol Chemical Corporation

Elkton Division

E1kton, MD 21921

Attn: O. D. Reed

Tensor Industries, Inc.

7777 Leesburg Pike

P. 0. Box 3072

Falls Church, VA 22043

Attn: J. V. Front

TRACOR, Inc.

6500 Tracor Lane

Austin, TX 78721

Attn: D. R. Sanders

TRACOR Marine, Inc.

P. 0. Box 13107

Port Everglades, FL 33316

Attn: Dr. M. L. Collier

U. S. Steel Corporation

600 Grant Street, Rm 2175

Pittsburgh, PA 15219

Attn: M. A. Burello 
University of South Carolina

Research and Institute Accounting

Treasurer's office

Columbia, SC 29208

Attn: Dr. 0. F. Schuette

Westinghouse Electric Corporation

Defense and Space Center

Friendship International Airport

Baltimore, MD 21203

Attn: G. T. Adams

R. E. Reise

J. W. Thomas, Jr.

Westinghouse Electric Corporation

Mail Stop 678, Box 1897

Baltimore, MD 21203

Attn: A. D. Collins

F. P. Hodges

Hughes Aircraft Corporation

1515 Wilson Boulevard

Arlington, VA 22209

Attn: Mr. Sullivan

Lockheed Missiles and Space Company

320 Logue Avenue

Mountain View, CA 94040

Attn: Dr. William F. Whitmore

Martin Marietta Aerospace

Orlando Division

Post Office Box 5837

Orlando, FL 23805

Attn: Mr. T. E. Dolan

Martin Marietta Aerospace

$1800 \mathrm{~K}$ Street NW

Washington, DC 20006

Attn: Mr. J. Sullivan

U. S. Naval Institute

Annapolis, MD 21402

National Academy of Sciences

2101 Constitution Ave NW

Washington, DC 20418

Attn: Lee Hunt 
Director

Naval Historical Center

Washington Navy Yard

Washinton, DC 20390

Attn: VADM E. Hooper

VADM Frederick L. Ashworth, USN(Ret)

Sunlit Hills

Route 非 3

P. O. Box $90 \mathrm{~T}$

Santa Fe, NM 87501

RADM Alexander S. Goodfellow, USN(Ret)

409 First Street

Coronado, CA 92118

Dr. William B. Graham

Head, Engineering Sciences Dept.

RAND Corporation

1700 Main Street

Santa Monica, CA 90406

Dr. William Q. Jeffers

Senior Scientist

McDonnel1 Douglas

Research Laboratories

P. O. Box 516

St. Louis, MO 63166

Dr. John F. Moore

1121 Denmark Road

Plainfield, N. J. 07062

Mr. John A. Saxten

135 Via Concha

Aptos, CA 95003

Professor Jerome Smith

Associate Professor

Aeronautical Engineering

Princeton University

Princeton, NJ 08540 

